\title{
DO UNTO OTHERS: THE IMPORTANCE OF BETTER COMPLIANCE WITH CONSULAR NOTIFICATION RIGHTS
}

\author{
Cindy Galway Buys*, SCOTt D. Pollock ${ }^{* *}, \&$ IOANa NaVARetTe \\ PELLICER ${ }^{* * *}$ \\ INTRODUCTION
}

Litigation involving the right of consular notification for foreign nationals arrested or detained in the United States has exploded in recent years. In the last decade alone, there were almost 400 cases in federal courts involving claims under the Vienna Convention on Consular Relations ("VCCR"). ${ }^{1}$ Additionally, three states sued the United States at the International Court of Justice ("ICJ") for violations of consular notification rights under Article 36 of the VCCR-Paraguay in Breard, ${ }^{2}$ Germany in LaGrand, ${ }^{3}$ and most recently Mexico in Avena, ${ }^{4}$ which involved fifty-four Mexican nationals who were on death row in the United States.

This Article explores some of the most interesting legal questions that are being raised in the area of consular notification rights. It explains why consular notification is important and how consular officers can assist when a foreign national is arrested or detained in the United States. It also

\footnotetext{
* Associate Professor and Director of International Law Programs, Southern Illinois University School of Law

${ }^{* *}$ Scott D. Pollock \& Associates, P.C., Chicago, IL

${ }^{* * *}$ Consul for the Protection Department, Consulate General of Mexico, Chicago. The views, opinions and comments expressed in this Article are those of the author as individual. They do not necessarily represent the official position of the Mexican Government or reflect the views, opinions or positions of the Ministry of Foreign Affairs (SRE).

1. Vienna Convention on Consular Relations, Apr. 24, 1963, 21 U.S.T. 77, 596 U.N.T.S. 261 [hereinafter Vienna Convention or VCCR]. Results of Westlaw search conducted on Dec. 4, 2010 of "ALLFEDS" database for cases using phrase "Vienna Convention on Consular Relations." These statistics represent only the tip of the iceberg because they do not include cases in states courts, or cases involving the more than 50 bilateral consular conventions to which the United States is a party.

2. Vienna Convention on Consular Relations (Breard) (Para. v. U.S.) 1998 I.C.J. 248 (Apr. 9).

3. LaGrand Case (F.R.G. v. U.S.), 2001 I.C.J. 466 (June 27).

4. See Case Concerning Avena and Other Mexican Nationals (Mex. v. U.S.), 2004 I.C.J. 12 (Mar. 31) [hereinafter Avena]. Mexico originally brought its claim on behalf of fifty-four Mexican nationals, but subsequently amended the claim to include only fifty-one Mexican nationals. See id. at 27, 29.
} 
discusses some state actions that have already been either proposed or taken to increase compliance with consular notification rights. It analyzes litigation strategies that have been pursued to remedy noncompliance and the success or failure of those strategies to date. Finally, the Article suggests some additional actions that may be taken in the future to better secure these important human rights.

\section{SCOPE AND PURPOSE OF CONSULAR NOTIFICATION}

\section{A. Brief History and Overview of Consular Relations Law}

Consular relations between sovereign states have existed for centuries. ${ }^{5}$ Prior to the adoption of the VCCR, the rules governing consular relations derived largely from customary practices developed over time and through a series of bilateral consular conventions. ${ }^{6}$ The duty and the right of consuls to protect their nationals abroad have been recognized by U.S. law for almost 200 years. ${ }^{7}$

In the $1950 \mathrm{~s}$, the international community recognized the need to codify the existing rules and practices governing consular relations. Hence, the General Assembly of the United Nations tasked the International Law Commission to draft a multilateral convention to bring more uniformity to the law of consular relations. ${ }^{8}$ The VCCR resulted from that process. Its final text was concluded and opened for signature in 1963, but it did not enter into force until $1967 .{ }^{9}$ The United States ratified the VCCR in $1969 .^{10}$

The basic functions of consulates are described in Article 5 of the VCCR. ${ }^{11}$ Broadly speaking, consular functions consist of protecting and

5. United Nations Conference on Consular Relations, Mar. 4-Apr. 22, 1963, Summary records of first plenary meeting, ๆ 57, U.N. Doc. A/CONF.25/16 (Mar. 4, 1963) (Statement by President Stephen Verosta). For a description of the historical development of consular relations, see Jaroslav Zourek, Special Rapporteur, Consular Intercourse and Immunities, Report of the Special Rapporteur, [1957] 2 Y.B. Int'1 L. Comm'n 71, 72-77, U.N. Doc. A/CN.4/SER.A/1957/ADD.1.

6. U.N. Conference on Consular Relations, Summary records of first plenary meeting, supra note 5, 54 (Statement by President Stephen Verosta).

7. "To watch over the rights and interests of their subjects ... is the great object for which Consuls are deputed by their sovereigns ...." The Bello Corrunes, 19 U.S. 152, 168 (1821); "Consuls shall, if the local authority arrest or prosecutes . . . take the necessary steps to have the [nationals] so arrested treated with humanity, defended and tried impartially." Mali v. Keeper of the Common Jail (Wildenhus's Case), 120 U.S. 1, 4 (1887).

8. United Nations Conference on Consular Relations, supra note 5, at 97 (Statement by President Stephen Verosta).

9. See http://treaties.un.org/Pages/ViewDetails.aspx?src=TREATY\&id=219\&chapter=3\&lang $=$ en (last visited May 12, 2011).

10. See id. The Vienna Convention is thus a part of the "supreme Law of the Land" under the U.S. Constitution. U.S. CONST. art. VI.

11. VCCR, supra note 2, at art. 5. 
facilitating the interests of a state and its nationals in the territory of another state. ${ }^{12}$ In particular, consular functions include: (1) promoting commercial, economic, cultural, and scientific relations between states; (2) issuing passports and other travel documents; (3) safeguarding the interests in the receiving state of the sending state's nationals, both individuals and corporate entities; (4) arranging appropriate representation of the sending state's nationals before the tribunals in the receiving state; (5) performing administrative functions such as acting as a public notary or serving judicial documents; and (6) exercising supervision and inspection of the sending state's national flag vessels and aircraft operating in the territory of the receiving state. ${ }^{13}$ Safeguarding the interests of the sending state and its nationals is considered the most important of these many consular functions. $^{14}$

\section{B. Requirements for Consular Notification under the VCCR}

The overarching purpose of the VCCR is to facilitate the exercise of consular functions, including the protection of foreign nationals abroad. ${ }^{15}$ Of particular relevance here, Article 36(1)(b) of the VCCR states that, if requested by a foreign national, the authorities of the receiving state shall, without delay, inform the consular post of the sending state that a national of that state has been arrested, committed to prison or to custody pending trial, or detained in any other manner. ${ }^{16}$ Article 36 further states that "said authorities shall inform the person concerned without delay of his rights under this sub-paragraph." ${ }^{17}$ Thus, federal, state and local authorities have a two-part duty under the VCCR: the first duty is to inform the foreign national who is arrested or detained of his or her right to have the authorities contact the appropriate foreign consulate, while the second duty is to notify the foreign consulate that a national of that consulate's country has been arrested or detained. Both of these duties must be performed "without delay."18

12. See, e.g., Summary Records of the $516^{\text {th }}$ Meeting, [1959] 1 Y.B. Int'1 L. Comm'n 165-66, U.N. Doc. A/CN.4/SER.A/1959 (Statements of Mr. Edmonds on draft articles 14 and 15).

13. VCCR, supra note 2, at art. 5.

14. United Nations Conference on Consular Relations, Mar. 4-Apr. 22, 1963, Commentary to Draft Articles on Consular Relations Adopted by the International Law Commission at its Thirteenth Session, 7, U.N. Doc. A/CONF.25/16.ADD 1 [hereinafter Commentary to Draft Articles].

15. See, e.g., Medellin v. Texas, 552 U.S. 491 (2008); Sanchez-Llamas v. Oregon, 548 U.S. 331, 367 (2006) (Breyer, J., dissenting).

16. VCCR, supra note 2, at art. 36(1)(b).

17. Id.

18. Id. 
Article 37 of the VCCR also contains some consular notification provisions. Subparagraph (a) sets forth the duty of state authorities to notify the appropriate consular posts when there is a death of a national of the sending state. ${ }^{19}$ Subparagraph (b) requires state authorities "to inform the competent consular post without delay of any case where the appointment of a guardian or trustee appears to be in the interests of a minor or other person lacking full capacity who is a national of the sending State." 20

C. Bilateral Treaties on Consular Relations

In addition to the VCCR, the United States is also a party to almost sixty bilateral consular conventions. ${ }^{21}$ Many of these bilateral consular conventions provide for more extensive or detailed consular notification rights than those included in the VCCR.

For example, consular notification under the U.S.-Russia Consular Convention $^{22}$ is different from the VCCR's consular notification obligations in at least two important respects. First, Article 12 of the bilateral convention requires that $"[\mathrm{t}]$ he appropriate authorities of the receiving state shall immediately inform a consular officer of the sending state about the arrest or detention in other form of a national of the sending state."23 Notification under this provision is mandatory in all cases, unlike the VCCR, which requires notification only if the foreign national so requests. Furthermore, notification is to occur "immediately" under the bilateral convention rather than "without delay" as under the VCCR.

Second, the Protocol to the U.S.-Russia Consular Convention further defines the requirement to provide immediate notification. It states that notification to the consular officer of the arrest and detention of one of its nationals shall take place within one to three days of the time of arrest or detention, depending on conditions of communication. ${ }^{24}$ The Protocol further states that the right of a consular officer to visit and communicate with a national of the sending state who is under arrest or otherwise detained shall occur within two to four days of the arrest or detention,

19. Id. at art. 37(a).

20. Id. at art. 37(b)

21. See U.S. Dept. of State, Bureau of Consular Affairs, Bilateral Consular Conventions, http://travel.state.gov/law/legal/treaty/treaty_784.html.

22. Consular Convention and Protocol (U.S.-U.S.S.R.), June 1, 1964, T.I.A.S. No. 6503, 19 U.S.T. 5018.

23. Id. at art. 12 .

24. Although the phrase "depending on conditions of communication" is not explained, a reasonable interpretation of the phrase in context would be that whether notice is given in one, two or three days depends on what is reasonable under the circumstances. 
depending on the location of the foreign national. ${ }^{25}$ Thus, the bilateral convention is more specific in defining when consular notification must occur as compared to the VCCR. ${ }^{26}$

The bilateral consular convention between the United States and China, which took effect in 1975, is another example. It provides authorities with a slightly longer period for consular notice, as follows:

If a national of the sending State is arrested or placed under any form of detention within the consular district, the competent authorities of the receiving State shall immediately, but no later than within four days from the date of arrest or detention, notify the consulate of the sending State. If it is not possible to notify the consulate of the sending State within four days because of communications difficulties, they should try to provide notification as soon as possible. Upon the request of a consular officer, he shall be informed of the reasons for which said national has been arrested or detained in any manner. ${ }^{27}$

By contrast, one of the newer bilateral consular conventions between the United States and Tunisia requires that:

The competent authorities of the receiving State shall, without delay, inform the appropriate consular post whenever a national of the sending state is the subject of an arrest or of any form of restriction on his personal freedom. For the purpose of this article, the term "without delay" contemplates that this notification will be made within three days following restriction on the freedom of nationals of the sending State, or in cases where the notification cannot be made within three days because of communications or other difficulties, as soon as possible thereafter. ${ }^{28}$

In addition to defining "without delay" to mean within three days, this Consular Convention between the United States and Tunisia makes consular notification mandatory upon arrest or any other form of deprivation of personal freedom of a foreign national, which language may be interpreted more broadly than "detention," ${ }^{29}$ such as being held for

25. Consular Convention and Protocol (U.S.-U.S.S.R.), supra note 22, at art. 12.

26. The meaning of "without delay" under the VCCR is discussed in more detail in Part IV infra.

27. Consular Convention (U.S.-China), art. 35, Sept. 17, 1980, U.S.-China, 33 U.S.T. 2973 (emphasis added).

28. Consular Convention (U.S.-Tun.), art. 39, signed May 12, 1988, Treaty Doc. 101-12, $101^{\text {st }}$ Cong., 2d Sess. (emphasis added).

29. Other examples of mandatory notification provisions may be found in Consular Convention, U.S.-Poland, art. 29, May 31, 1972, 24 U.S.T. 1231 and in Consular Convention, U.S.-U.K., art. 16, June 6, 1951, 3 U.S.T. 3426. See also Bureau of Consular Affairs, U.S. DeP'T of State, CONSUlAR NOTIFICATION AND ACCESS 47 (2003), available at http://travel.state.gov/law/ consular/consular_636.html. 
questioning, placed under house arrest or having one's passport or other travel documents confiscated.

The vast majority of countries now belong to the multilateral VCCR. ${ }^{30}$ Hence, the United States rarely enters into new bilateral conventions any longer. ${ }^{31}$ However, the discussion above highlights a few examples of the different requirements that may be contained in some of these bilateral consular conventions, particularly with regard to the requirement for mandatory notification of the consulate within a defined period of time of arrest or detention.

\section{WHY IS CONSULAR NOTIFICATION IMPORTANT?}

In cases where foreign nationals arrested or detained in the United States alleged that they did not receive notice of their right to communicate with their consulate, many courts have held that the defendant must show that he or she was prejudiced by the lack of consular notification before obtaining any relief. ${ }^{32}$ In several of these cases, judges have made statements suggesting that consular assistance would not have made a difference. ${ }^{33}$ This raises a concern that some judges do not understand what kinds of help a consulate may be able to provide in these situations and how vital that assistance can be. Accordingly, this next section discusses the types of assistance that a consulate may provide and how it can make a difference for a foreigner who has been arrested or detained in the United States.

30. As of this writing, there are 162 States Parties to the Vienna Convention on Consular Relations, plus the Holy See. See http://travel.state.gov/law/consular/consular_744.html\#vienna (last visited May 12, 2011). Currently, there are only seven States that have a bilateral consular agreement with the United States but who are not also parties to the VCCR. See U.S. State Dept. Bureau of Consular Affairs, http://travel.state.gov/law/legal/treaty/treaty_784.html (last visited May 12, 2011).

31. With respect to the relationship between the VCCR and bilateral consular agreements, Article 73 of the VCCR provides: "1. The provisions of the present Convention shall not affect other international agreements in force as between the States parties to them. 2. Nothing in the present Convention shall preclude States from concluding international agreements confirming or supplementing or extending or amplifying the provisions thereof. VCCR, supra note 2, at art. 73.

32. See e.g., United States v. Rangel-Gonzales, 617 F.2d 529, 530 (9th Cir. 1980); United States v, Esparza-Ponce, 7 F.Supp.2d 1084, 1096-97 (S.D.Cal. 1998); United States v. Briscoe, 69 F.Supp.2d 738, 747 (D. Virgin Islands 1999); Iowa v. Lopez, 633 N.W.2d 774, 783 (Iowa. 2001); Colorado v. Preciado-Flores, 66 P.3d 155, 161 (Colo. App. 2002); Hernandez v. United States, 280 F.Supp.2d 118, 124-25 (S.D.N.Y. 2003).

33. See e.g., Faulder v. Johnson, 81 F.3d 515, 520 (5th Cir. 1996); Darling v. Florida, 808 So.2d 145,166 (2002). 
A. Examples of the Important Assistance that a Consulate Can Provide

Noncitizens in the United States are placed in a difficult situation when they are in state or federal custody due to pending criminal or immigration proceedings. They are frequently hampered by their limited English language ability and an unfamiliarity with both their legal rights and the U.S. legal process. They may have been separated from family members who are suddenly without any means of support and who likely lack information about what is happening to their loved one. ${ }^{34}$ The underlying reason for consular protection is that the consul, by communicating with its national, has the capacity to ensure that the person's basic human rights are respected, confirm the physical integrity and healthy mental state of the foreign national, and verify that no violation of rights has taken place (e.g., excessive force during arrest, coercion to confess). ${ }^{35}$

Often a criminal defendant and his or her attorney are unaware of the defendant's status under immigration law, or of the drastic immigration consequences that may flow from pleading guilty to a crime or a finding of guilt. Historically, courts would often disregard mistakes in accepting guilty pleas from noncitizens, due to the so-called "collateral consequences doctrine," which prohibited a collateral attack on a criminal conviction in a subsequent immigration proceeding. ${ }^{36}$ That is now changing following the U.S. Supreme Court's recent decision in Padilla v. Kentucky, ${ }^{37}$ where the Court held that an attorney's failure to advise a defendant of the immigration consequences of a guilty plea in a criminal proceeding may constitute ineffective assistance of counsel under the Sixth Amendment to the U.S. Constitution. However, other problems remain. The next section explains why timely consular notification is important and how it can make a difference using examples from the actions of the Mexican consulate in Chicago, Illinois.

34. Families affected by immigration consequences of crimes are often separated with no hope of ever being reunited in the United States. See DePt. OF Homeland SECURITY OfFICE OF INSPECTOR

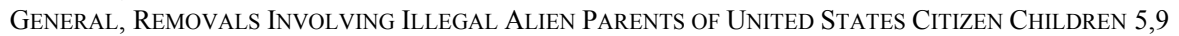
(2009) (reporting more than 100,000 noncitizen parents of U.S. citizen children were removed between Fiscal Years 1998 and 2007, many of whom are removed owing directly to having one or more criminal convictions); see also Lynne Lamberg, Children of Immigrants May Face Stresses, Challenges That Affect Mental Health, Journal of American Medical Association, Aug. 20, 2008 ("The recent intensification of immigration enforcement activities by the federal government has put children of undocumented parents at increasing risk of family separation, economic hardship, and psychological trauma.").

35. On timely access to detainees and its reasons, see U.S. DEP'T OF STATE, FOREIGN AFFAIR MANUAL 7 FAM 422 (2004), available at http://www.state.gov/documents/organization/86605.pdf.

36. Padilla v. Kentucky, 253 S.W.3d 482 (Ky. 2008).

37. Padilla v. Kentucky, 130 S.Ct.1473 (2010). 


\section{The Importance of Timely Consular Notification Generally}

In the experience of the Mexican consulate, consular notification is almost never provided when a foreign national is detained at a port of entry, such as at an airport. Consular notice is not given even though the person has been denied entry to the United States, placed in detention, segregated from other airport access areas and, in some cases, made to wait more than twenty-four hours for the next flight back to the person's place of origin. This lack of consular notification is particularly problematic because that detained individual will not have access to resources needed to obtain the correct documentation that might be necessary to clarify the situation. $^{38}$

A good example is a case that came to the attention of the Mexican consulate General of Chicago after the fact. A Mexican lady, Ms. Perez, traveling with her daughter Ana, stopped in Chicago on their way to Russia. $^{39}$ Ana was being sponsored by Mexican organizations to represent Mexico in multiple performances as part of a music festival in Russia; she had a connecting flight in Chicago at O'Hare International Airport. When they went through customs at O'Hare Airport, Ms. Perez was told that she had overstayed her tourist visa and that the authorities suspected she was living in the United States without the proper authorization. She denied the allegation and provided information to prove that she had re-entered the United States at a border port of entry prior to this time without any problems. She was not allowed to present any supporting documents of her employment in Mexico or her daughter's school records to prove that she had continuously resided in Mexico. Those documents were in her suitcase, to which she was denied access. Therefore, she never had the opportunity to rebut the allegations. Both Ms. Perez and Ana were denied admission into the United States and their visas were cancelled. They were detained and segregated in a room for several hours before they were placed on another flight back to Mexico. The Mexican Consulate was never notified by the authorities, but learned about this case once Ms. Perez and Ana were returned to Mexico. These Mexican nationals missed their flight to Russia and lost the opportunity to represent Mexico at some of the cultural events they were supposed to attend. Ana eventually flew to Russia without her

38. Oftentimes, if the detained person is given one opportunity to make a phone call, the person chooses to call a family member rather than the consulate. If independent notice is provided to the consulate, the consular officer can listen to the detainee's story, assess the situation and offer appropriate assistance.

39. The names have been changed to protect the privacy of the persons involved. 
mother because they could not afford to pay for two additional tickets. This time the layover was in Canada. ${ }^{40}$

All of this might have been prevented if the Mexican consulate had been allowed to intervene on their behalf. Ms. Perez would have been able to present documentation regarding her residence in Mexico and the consulate would have requested that the immigration authorities reconsider allowing them to take their flight to Russia.

\section{Consular Assistance in Criminal Cases}

Timely consular access also is crucial in criminal cases to allow consuls to perform a number of services, including advising foreign nationals on the U.S. legal system, such as the right to remain silent, transmitting to courts and other competent authorities information and proposals that may help safeguard the rights of the foreign national, bringing to the attention of the court relevant provisions of international agreements, and arranging for legal representation of nationals. ${ }^{41}$ The consular official will often secure legal advice or representation for its national, when necessary, as soon as possible in order for its national to have a full understanding of the charges and the legal process he or she is facing. ${ }^{42}$ For example, the Mexican consular office is likely to secure independent legal advice for nationals arrested and detained in jurisdictions where it has been detected by the consular office that certain local authorities tend to mistreat foreign detainees, or where the seriousness of the accusation merits the exception of not waiting until the detainee is assigned a public defender.

It has been the experience of the Mexican consulate officials in Chicago that having consular access to a national at the moment of detention makes a significant difference in how the case develops. In one instance, the Consulate General of Mexico assisted a Mexican national who was facing a first degree murder charge, Rosa Martínez, by securing legal representation as soon as she was detained. The Mexican Consulate was not given consular notification by the arresting authorities in this case, but instead learned about it through the newspaper on the morning that Ms. Martínez was detained, allegedly for the murder of her minor child. ${ }^{43}$ Given that the city where Ms. Martínez was arrested was a two-hour drive away,

\footnotetext{
40. Confidential Files of the Consulate General of Mexico, Chicago (on file at the Consulate Representation).

41. Commentary to Draft Articles, supra note 14, at 8.

42. See U.S. DEP'T OF STATE, supra note 35, at 7 FAM 422 (on explaining legal process in foreign country to detainee).

43. As before, fictitious names have been used to protect the privacy of those involved.
} 
the consular official called the local police department responsible for Ms. Martínez's detention and interrogation and requested immediate consular access via telephone. Consular access was denied by the authorities, who stated that she was having a breakdown and had herself refused to speak to a consular official.

The consular official then drove to the police station with a criminal defense attorney who works with the consulate in a consulting capacity and on pro bono cases. When they arrived, Ms. Martínez had already been transferred to the county jail. They visited Ms. Martínez there. She was in a total state of shock, not making much sense of anything. She kept saying that her daughter was dead and that it was her fault. She talked about being attacked in her sleep and defending herself against her attacker. She described other things that did not make sense but could not be construed as a confession. In any case, she obviously was not in a state of mind to be interrogated by police authorities.

The consular official then requested that the consulting attorney take the case given the serious nature of the charges and the extreme media coverage that the heinous crime was already being given-it would be several days before Ms. Martínez was assigned a public defender who could start actually working on the case (other than the attorney assigned that week for initial appearances). That first interview between Ms. Martínez and her attorney proved crucial because it gave reason to investigate her medical records and other background information, and to request a follow-up of the crime scene investigation by the police. Ms. Martínez was taking anti-depressant medication that had side effects such as loss of memory and sleep disorders. Furthermore, the attorney was able to ascertain that there was a slashed window screen with a footprint beneath it and traces of blood at the crime scene, which police authorities had not followed up on. The attorney's defense centered on the theory that there had been someone else at the scene and that Ms. Martínez might have been a witness to the crime in a half-sleep state. The first positive result to this timely, in-depth investigation by the defense attorney was to obtain a statement from the State Attorney's Office that the state would not seek the death penalty on this case. The case is still pending, but additional information gives reason to believe that Ms. Martínez may be innocent. It was the timely intervention of the consular officer that gives reason to hope that an innocent woman may not be wrongly convicted and imprisoned for the murder of her daughter. ${ }^{44}$

44. Confidential Files of the Consulate General of Mexico, Chicago (on file at the Consulate Representation) 


\section{Language and Cultural Barriers}

Language and culture can also create barriers to effective communication and increase the need for prompt consular access. Within some cultures, there is a reaction to any authority figure that is known as "gratuitous acquiescence," whereby persons from that culture may believe that complete and total respect and deference is owed to police officers and, as a result, they would not dare contradict an officer's statement. ${ }^{45}$ For example, the police officer or the investigator may state a question in an affirmative manner, "You were there at the time the incident happened, isn't this correct?" In response, the person will say "yes," even though the real answer is "no." The person being interrogated may believe that there is less risk involved in lying than in upsetting the authority figure by stating something different than what the authority figure expects. An interrogation of a detainee under these circumstances will probably result in a wrongful perception of that person's involvement or participation in the case.

Language interpretation problems are also common. Interpretation of a language consists not only of the words but the attitude and the cultural background of the foreign language-speaking person. Those subtleties can only be detected by a person who understands the culture and the customs of the foreigner's country. Translations are often not literal and, if the interpreter is not well-trained, the interpretation may be incorrect or biased. In some cases, Mexican consular officials have learned of police officers acting as interpreters or document translators for the detainee. Other times, family members, even minors, are used for these purposes. Although family members may be familiar with the culture, they are not properly trained as professional legal interpreters or translators and their amateur efforts may inadvertently lead to miscommunication due to fear, bias, incomplete translations or a lack of knowledge of vocabulary and other subtleties.

Other times, it is common that a lack of communication by a detainee with the arresting officer or even the defense attorney is confused with an intention to deceive or a lack of willingness to cooperate. In such situations, cultural and language barriers are misinterpreted. For example, in the Mexican culture, indigenous or poorly educated individuals show the

45. See Susan Berk Seligson, Coerced Confessions: The Discourse of Bilingual Police INTERROGATIONS 102-10 (2009) (The phenomenon is also known as "gratuitous concurrence" and has been observed in Aboriginal English speakers in Australia and among Meso-American cultures in Costa Rica, Mexico and El Salvador, among others). Similarly, clients from cultures that punish those challenging government action may be resistant to take appeals or other actions that challenge a government decision. See Sue Bryant and Jean Koh Peters, Five Habits for Cross Cultural Lawyering, in RACE, CUlture, PSYCHOLOGY, AND LAW 47-62 (Kimberly Barrett \& William George eds., 2004). 
type of "gratuitous acquiescence" towards authority figures that was discussed above.

A lack of communication can also result from a lack of understanding due to an underlying mental disability or because the speaker is communicating in an indigenous language that the interrogator does not recognize. Consuls may be able to recognize an indigenous speaker and provide a proper interpreter. And when the language and cultural barriers are gone, consuls may also be able recognize that there is something else that should be addressed and requires attention, such as a mental disability. It also is possible that the inability to properly communicate may be misinterpreted as a mental disability. For example, an indigenous person may be wrongfully identified as such-that detainee might be dealt with as being a speaker of the official language of his or her country when in reality this person might only speak an indigenous language. For example, take the case of Cirila Baltazar Cruz, an indigenous woman from the state of Oaxaca in Mexico, who speaks neither English nor Spanish. ${ }^{46}$ She was declared unfit to raise her child by the state of Mississippi because the Spanish interpreter could not communicate with her. But, in fact, Ms. Cruz could not understand the interpreter because she only speaks an indigenous tongue. Her lack of communication and understanding was interpreted as a mental disability. ${ }^{47}$

In this case, there was no consular notification regarding the removal of a Mexican baby from her mother's custody or of the custody proceedings that were initiated by the state authorities, as required under Article 37 of the VCCR. ${ }^{48}$ All of the above demonstrates the importance of a consular official's interview with its national.

\section{Lack of Understanding of Legal Procedures}

Persons from other countries often have little knowledge of the U.S. legal system and the rights they may have when they are in the United States. To assist in addressing this problem, the Government of Mexico has signed several Memorandums of Understanding ("MOU") with state agencies throughout the United States that deal with child and family welfare issues, particularly with respect to the need for consular notification in cases of abuse or neglect of Mexican or Mexican-American

46. See Tim Padgett with Dolly Mascareñas, Can a Mother Lose Her Child Because She Doesn't Speak English? TIME, Aug. 27, 2009, available at www.time.com/time/nation/article/ 0,8599,1918941,00.html.

47. Confidential Files of the Consulate General of Mexico, Chicago (on file at the Consulate Representation)

48. See VCCR, supra note 2, at art. 37. 
children. These MOUs are extremely important in ensuring that foreignborn parents understand the procedures that they will face. Some of these procedures may result in the loss of the custody or the parental rights to their children.

For example, the Consulate General of Mexico in Chicago signed a MOU with the Department of Children and Family Services ("DCFS") of Illinois regarding consular notification in cases involving Mexican children. DCFS has the power to take a child from his or her parents and place that child with a guardian if there is a concern regarding abuse or neglect. ${ }^{49}$ Article 37 (b) of the VCCR provides that the authorities have the duty:

[T]o inform the competent consular post without delay of any case where the appointment of a guardian or trustee appears to be in the interests of a minor or other person lacking full capacity who is a national of the sending State. The giving of this information shall, however, be without prejudice to the operation of the laws and regulations of the receiving State concerning such appointments. ${ }^{50}$

Despite this legal requirement, it is common that the Mexican consulate does not receive notification in cases where a guardian is appointed to look after the interests of a minor from Mexico. The consulate often learns of these cases only when the parents come into the consulate requesting assistance.

Nevertheless, in some cases DCFS does comply and the case develops differently because of it. An example of the relevance of consular notification in custody cases is the story of Juanito. ${ }^{51}$ In his case, the consulate received notice indicating that Juanito is a U.S.-born child whose parents are Mexican nationals. As soon as the notification was received, the consular official contacted Juanito's parents and the investigator in the case. The consular official then learned that the parents and Juanito only spoke Spanish and the investigator only spoke English. At that time, the child had already been removed from the home for alleged abuse. Juanito had been placed in a non-Spanish speaking home and all of the initial interviews of him had been conducted with the assistance of a telephone system interpreter.

The situation was addressed by the consulate with DCFS and the child was placed in a Spanish-speaking home; the investigator was changed to

49. See Child and Family Services Act, 20 ILCS 505.

50. VCCR supra note 2, at art. 37(b). The requirements of article 37 of the VCCR are discussed in more detail in II.B infra.

51. Once again, the name has been changed to protect the identity of a minor. 
one that spoke Spanish, and the parents were informed that they had the right to understand the procedure and to have an attorney who could communicate fluently with them (through an interpreter if necessary) to represent them if the case was presented to a court. This assistance gave the parents a sense of calm and the patience to endure the slow progress of the case. In Juanito's case, the initial interviews that had been conducted with the assistance of an interpreter on the phone did not contain the in-depth information required to sustain the allegations of abuse and the child eventually was returned to his parents' home. Those errors were corrected because the consulate was notified and was able to timely intervene. ${ }^{52}$

Another area in which problems have arisen is the area of plea bargaining. Some noncitizens wrongly believe that acceptance of a plea bargain will not make them deportable. In fact, any entry of a guilty plea or admission of sufficient facts to warrant a finding of guilt, coupled with some form of punishment, penalty or restraint on a person's liberty, constitutes a conviction within the meaning of the immigration law. ${ }^{53}$ Moreover, in addition to the severity of the direct consequences of a criminal conviction, the collateral immigration consequences of a criminal conviction can be equally or more devastating. As the U.S. Supreme Court has noted:

The impact of deportation upon the life of an alien is often as great if not greater than the imposition of a criminal sentence. A deported alien may lose his family, his friends, and his livelihood forever. Return to his native land may result in poverty, persecution and even death. ${ }^{54}$

As demonstrated above, consular notification by the arresting or detaining authority under Articles 36 and 37 of the VCCR can alleviate some of the confusion and isolation experienced by detained noncitizens and their families. Consular officers can explain certain fundamental rights and basic legal procedures, which may lead to a favorable outcome in the underlying criminal or immigration proceeding. At the very least, intervention by a consular officer of the foreign national's home country can provide a "cultural bridge" between the noncitizen detainee and the legal machinery of the receiving state. One court, recognizing "the unique assistance that can be provided by the consulate," noted:

52. Confidential Files of the Consulate General of Mexico, Chicago (on file at the Consulate Representation)

53. INA § 101(a)(48)(A) (2010); 8 U.S.C. § 1101(a)(48)(A) (2010).

54. Bridges v. Wixon, 326 U.S. 135, 164 (1945); See also Padilla v. Kentucky, 130 U.S. 1473, 1481 (2010) ("We have long recognized that deportation is a particularly severe 'penalty,' quoting Fong Yue Ting v. United States, 149 U. S. 698, 740 (1893).”). 
The consulate can provide not only an explanation of the receiving state's legal system but an explanation of how that system differs from the sending state's system. This assistance can be invaluable because cultural misunderstandings can lead a detainee to make serious mistakes, particularly where a detainee's cultural background informs the way he interacts with law enforcement officials and judges. ${ }^{55}$ ... In addition, the consulate has a more practical role to play in U.S. legal proceedings:

The consulate can do more than simply process passports, transfer currency, and help contact friends and family back home. The consulate can provide critical resources for legal representation and case investigation. Indeed the consulate can conduct its own investigation, file amicus briefs and even intervene directly in a proceeding if it deems it necessary. Importantly, the consular officer may help a defendant in obtaining evidence or witnesses from the home country that the detainee's attorney may not know about or be able to obtain. ${ }^{56}$

\section{B. How Consular Notification Can Make a Difference in Immigration Proceedings}

Unlike in criminal proceedings, a foreign national does not have a right to defense counsel provided by the government in immigration proceedings. ${ }^{57}$ A consular official's help in securing adequate representation for foreign nationals in both the criminal proceeding and the immigration proceeding can assist the foreign national to avoid deportation because many of the immigration consequences of a criminal proceeding may not be apparent to criminal defense counsels or to judges. For example, a sentence of supervision or probation that is not considered a conviction under state law can remain a conviction for federal immigration purposes and can subject the noncitizen to deportation. ${ }^{58}$ Further, a state criminal conviction that is vacated, or a guilty plea that is withdrawn, remains a conviction for federal immigration purposes if the reason for the post-conviction action is based on equitable concerns relating to a defendant's rehabilitation or to allow a foreign national to remain in the United States. ${ }^{59}$ State court judges and attorneys also may not be aware that a misdemeanor conviction in state court may be treated as an "aggravated felony" in immigration proceedings, virtually assuring deportation of the

\footnotetext{
55. Osagiede v. U.S., 543 F.3d 399, 403 (7th Cir. 2008).

56. Id. (citations omitted).

57. INA $\S \S 240(b)(4)(A), 392 ; 8$ U.S.C. $\S \S 1229(b)(4)(A), 1362$.

58. See, e.g., Gill v. Ashcroft, 335 F.3d 574 (7th Cir. 2003) (noting that INA $\S 101(\mathrm{a})(48), 8$ U.S.C. $\S 1101(\mathrm{a})(48)$ federal definition of conviction satisfied by Illinois sentence of 1410 probation).

59. See, e.g., Ali v. Ashcroft, 395 F.3d 722, 727 (7th Cir. 2007).
} 
foreign national. ${ }^{60}$ The difference of one day in a sentence can determine whether a theft offense has no immigration consequence or is an aggravated felony that will result in automatic deportation. ${ }^{61}$ Until recently, some circuit courts ruled that two state misdemeanor drug possession convictions may constitute a federal drug trafficking crime and an aggravated felony for immigration purposes. ${ }^{62}$

To complicate matters, at any given time there may be deep splits among the federal circuit courts of appeal on many immigration law issues, ${ }^{63}$ so it is difficult or impossible to generalize the particular immigration consequences of a specified crime. A consular official may be instrumental in identifying experienced immigration counsel who can work together with criminal defense counsel to fashion an immigration safeharbor plea, or otherwise minimize the likelihood of deportation resulting from a finding of guilt or a guilty plea to an aggravated felony or other deportable offense. ${ }^{64}$

Aside from the criminal process, many noncitizens convicted of crimes in the United States are now subject to mandatory immigration detention..$^{65}$ The Department of Homeland Security's ("DHS") Immigration and Customs Enforcement ("ICE") will often place an immigration detainer on a state or federal prisoner, who is then ineligible for release from custody and is transferred directly to ICE custody until the conclusion of

60. Gattem v. Gonzales, 412 F.3d 758 (7th Cir. 2005); Espinosa-Franco v. Ascroft, 394 F.3d 461, 464-65 (7th Cir. 2005).

61. INA $\S 101(\mathrm{a})(43)(\mathrm{G}) ; 8$ U.S.C. $\S 1101(\mathrm{a})(43)(\mathrm{G})(2010)$.

62. U.S. v. Pacheco-Diaz, 506 F.3d 545, 548-50 ( $7^{\text {th }}$ Cir. 2007) reh'g denied 513 F.3d 776 (7th Cir. 2008), overruled by Carachuri-Rosendo v. Holder, 130 S.Ct. 2577 (2010).

63. There are presently many unresolved circuit court splits that may determine whether a noncitizen will be deported based only on where he or she is detained and removal proceedings occur. These include: whether an expungement under a state analog to the Federal First Offender Act constitutes a conviction for federal immigration purposes, see Lujan-Armendariz v. INS, 222 F.3d 728 (9th Cir. 2000)(only circuit court to hold expungement not a conviction); whether a conviction for a crime constituting a ground of removal without a corresponding ground of inadmissibility may be waived under INA Section 212(c), see Blake v. Carbone, 489 F.3d 88 (2d Cir. 2007) (only circuit court holding that the BIA's statutory counterpart rule violates equal protection); whether a long-term lawful resident convicted by trial as opposed to by a guilty plea before the 1996 INA amendments remains eligible to apply for a 212(c) waiver, cf. Atkinson v. Att'y Gen., 479 F.3d 222 (3rd Cir. 2007) (reliance on pre-1996 law not required) and Canto v. Holder, 593 F.3d 638 (7th Cir. 2010) (reliance is categorically required); whether a parent can claim asylum based on fear of female genital mutilation to his/her child, see Benyamin v. Holder, 579 F.3d 970, 977-78 (9th Cir. 2009) (yes) and Kane v. Holder, 581 F.3d 231, 239 (5th Cir. 2009) (no); whether a conviction for use of a false social security number, an increasingly common charge against noncitizens, constitutes a crime involving moral turpitude that would bar relief from removal, c.f. Beltran Tirado v. INS, 213 F.3d 1179 (9th Cir. 2000) (no) and Hyder v. Keisler, 506 F.3d 388, 391-92 (5th Cir. 2007) (yes).

64. See generally Padilla v. Kentucky, 130 S.Ct. 1473, 1473 (2010).

65. See 8 U.S.C. $\$ 1226(c)$ (2010). 
the civil immigration proceedings. Immigration detention can sometimes last longer than a criminal sentence, even when the detainee does not contest his or her deportation. Often, depending on the availability of detention space in a particular location, or for other reasons, ICE will transfer an immigration detainee away from his or her family, his attorney, and/or witnesses that could appear in a local immigration court. The venue of the proceedings may determine whether the detainee is eligible for release on bond or relief from removal. In some cases, a consular official may advocate and prevail upon ICE to maintain custody near the detainee's home or in a more favorable judicial circuit. Consular officials may be instrumental in assisting the detainee to provide a travel document to the ICE Detention and Removal officer, in arranging a bond, in urging a quick resolution of the immigration proceedings, or in providing information to family members on a detainee's location, health, and the process that they can expect to happen. As noted above, consular officers may also be able to assist the detainee in finding competent legal counsel, which is especially important in immigration proceedings where, unlike in criminal proceedings, there is no right to a government-provided attorney. ${ }^{66}$

One issue that sometimes arises with persons placed in immigration detention is when the right to consular notification and the right to contact a consulate attaches. The federal immigration regulation implementing Article 36 of the VCCR only refers to a "privilege of communication," which states that every detained alien shall be notified that he or she may communicate with consular or diplomatic officers. ${ }^{67}$ An immigration detention occurs when someone is arrested on a warrant issued by the Attorney General or Secretary of Homeland Security. ${ }^{68}$ According to ICE, the agency within the DHS charged with interior enforcement of the immigration laws, almost 400,000 persons are detained each year on immigration-related charges. ${ }^{69}$ But the regulation does not track Article 36, in that it does not direct that the notification be given without delay, or in any particular time for that matter.

The United States immigration authorities will normally contact the foreign national's consulate to obtain necessary travel documents and to confirm the person's identity and nationality to facilitate his or her removal

66. See INA $\S \S 240(b)(4)(A), 392 ; 8$ U.S.C. $\S \S 1229 a(b)(4)(A), 1362$. On the importance of effective assistance of counsel, see Padilla, 130 S.Ct. at 1473.

67. 8 C.F.R. $\S 236.1(\mathrm{e})$ (2008). This issue of when consular notice must be given is dealt with in more detail in Part IV below.

68. 8 U.S.C. $\S 1226(\mathrm{a})$.

69. U.S. Department of Homeland Security Annual Report, Immigration Enforcement Actions: 2009, August 2010 available at: http://www.dhs.gov/xlibrary/assets/statistics/publications/ enforcement_ar_2009.pdf. 
to that country. But in some custodial situations, United States immigration authorities take the position that no notice is required. ${ }^{70}$ For example, persons arriving at a port of entry with primary or secondary inspection who are subject to expedited removal are considered to have not made an entry to the United States and thus the consulate is often not notified before the person is removed from the United States. ${ }^{71}$

For mandatory notice countries, ${ }^{72}$ the regulation provides for "immediate communication with appropriate consular or diplomatic officers whenever nationals of the following countries are detained in removal proceedings, whether or not requested by the alien and even if the alien requests that no communication be undertaken in his or her behalf." ${ }^{13}$ The Immigration and Nationality Act contains two types of removal proceedings, one that is overseen by an immigration judge, ${ }^{74}$ and the other that results in expedited removal of arriving aliens without a hearing. ${ }^{75}$ Noncitizens in both types of proceedings may be detained pending completion of the proceedings, and ICE's published detention standards call for consular notification. ${ }^{76}$ Although DHS has a legal duty to follow federal law regarding consular notification, it is not certain how carefully and consistently DHS implements this duty, especially when an expedited removal occurs shortly after the detention itself. A lack of consular notice under these circumstances is not inconsequential since persons subject to expedited removal can be erroneously removed from the United States without being provided a hearing or review of the order. And once ordered

70. There are two different immigration authorities that are often involved in immigration proceedings. The U.S. Customs and Border Control (CBP) generally has jurisdiction over entry ports and points while the U.S. Immigration and Customs Enforcement (ICE) primarily has jurisdiction over immigrants after they have entered the country.

71. Cindy Buys and Mark Wojcik, U.S. Airport Arrests without Consular Notice May Violate Treaties, INTERNATIONAL LAW NEWS (Spring 2008).

72. See discussion of mandatory notification countries in Part I.C supra.

73. 8 C.F.R. $\S 236.1(\mathrm{e})(2008)$.

74. 8 U.S.C. $\$ 1229 \mathrm{a}(2010)$.

75. 8 U.S.C. $\$ 1225(\mathrm{~b})$.

76. See ICE/DRO Detention Standard, U.S. IMMIGRATION AND Customs ENFORCEMENT, 1 (Dec. 2, 2008), http://www.ice.gov/doclib/dro/detention-standards/doc/visitation.doc ("The expected outcomes of this Detention Standard are: . . . (3) Detainees will be advised of their right to contact their consular representatives and receive visits from their consulate officers.") Because these detention standards are not codified by law or regulation, they are not considered legally binding on the agency. See also Moving Toward More Effective Immigration Detention Management: Hearing Before the Subcomm. on Border, Maritime and Global Counterterrorism of the H. Homeland Security Comm. (2009) (statement of Mary Meg McCarthy, Executive Director, Heartland Alliance's National Immigrant Justice Center), available at http://www.immigrantjustice.org/resourcespolicy/policydocs/ detentionmanagementhearingstatement.html. 
removed, the alien is usually barred from returning to the United States for at least five years and often longer. ${ }^{77}$

In one case known to the authors, a man with a pending application for adjustment of status to that of a lawful permanent resident ${ }^{78}$ was returning from a temporary visit to his home country using a travel document known as an advance parole document. ${ }^{79}$ Upon arriving at O'Hare airport in Chicago, U.S. Customs and Border Protection ("CBP") officials detained him and issued an order of expedited removal against him as an inadmissible "arriving alien." ${ }^{80}$ CBP did not notify the detainee's consulate, nor was he notified of his right to contact his consulate. Instead, his family members, concerned with his not calling them upon his arrival, contacted counsel who called CBP and learned of its actions. Counsel informed CBP that persons who have been granted an advance parole are not subject to expedited removal as arriving aliens. ${ }^{81} \mathrm{CBP}$ refused to reverse its decision and placed the detainee on a plane to be removed to his country in Africa. Counsel filed a petition for habeas corpus and a federal district judge entered a temporary stay of removal, requiring CBP to retrieve him from the plane. Shortly after, counsel and the government agreed that he would be released and allowed to pursue his adjustment of status application. Had CBP respected the detainee's VCCR right to consular notification, it might have averted a federal lawsuit or possibly would have provided the agency with an incentive to reflect on its actions, follow the statute, and afford due process to an applicant for admission.

As with criminal proceedings, ${ }^{82}$ an immigrant cannot normally mount a collateral attack against his or her deportability based on the grounds that the defendant was not advised of rights under Article 36 of the VCCR. ${ }^{83}$ Thus, once the right to consular notification has been disregarded, it may be too late to remedy the violation. For the right to be meaningful, any United States detaining official should notify the detainee of their rights

77. See 8 U.S.C. $\S 1182(a)(9)(A)$ (effective Nov. 30, 2010).

78. 8 U.S.C. $\S 1255$. In this particular case, the foreign national was married to a U.S. citizen and had four U.S. citizen children.

79. 8 U.S.C. $\S 1182(d)(5)$ (effective Nov. 30, 2010) (granting advance parole to certain aliens).

80. 8 U.S.C. $\S 1225(b)(1)$ (governing expedited removal); 8 C.F.R. $§ 1.1(q)$ (2010) (defining an "arriving alien").

81. 8 C.F.R. $\S 1.1(\mathrm{q})$ ("The term arriving alien means an applicant for admission coming or attempting to come into the United States at a port-of-entry" except that an alien who was granted "advance parole which the alien applied for and obtained in the United States prior to the alien's departure from and return to the United States, will not be treated . . . as an arriving alien under section 235(b)(1)(A)(i) of the Act.") see Am. Arab Anti-Discrimination Comm. v. Ashcroft, 272 F. Supp. 2d 650 (E.D. Mich. 2003).

82. See Medellín v. Texas, 552 U.S. 491, 491 (2008).

83. Matter of Rivera-Valencia, 24 I. \& N. Dec. 484, 491-92 (BIA 2008). 
under Article 36 at the first possible instance, even if the detention is to last a short period of time.

\section{CAN CONSULAR NOTIFICATION RIGHTS BE ENFORCED IN U.S. COURTS?}

Under Article VI the U.S. Constitution, treaties are part of "the supreme Law of the Land; and the Judges in every State shall be bound thereby." ${ }^{84}$ Thus, the VCCR is part of binding federal law. Assuming that a foreign national believes his or her consular notification rights have been violated, one important and unresolved legal issue is whether the VCCR creates a cause of action such that a party may bring suit in a court in the United States to enforce the treaty. In order to answer this question, it must first be determined whether the VCCR is a self-executing treaty. ${ }^{85}$ Only then could the treaty give rise to a cause of action to enforce any rights that may be granted under that treaty.

\section{A. Is the VCCR a Self-Executing Treaty?}

Thus far, the U.S. Supreme Court has not squarely decided whether the VCCR is self-executing, holding in Medellin v. Texas only that the ICJ's judgment finding that the United States had violated Article 36 of the VCCR was not a self-executing domestic legal obligation-side-stepping the issue of the self-executing nature of the underlying treaty itself. ${ }^{86}$ However, every lower court that has considered the issue has expressly held that the VCCR is self-executing. ${ }^{87}$ There also is evidence that the political branches considered the treaty to be self-executing at the time of ratification. ${ }^{88}$ When the executive branch submitted the VCCR to the Senate for its advice and consent, State Department Deputy Legal Advisor J. Edward Lyerly testified that "[t]he Convention is considered entirely self-executive and does not require any implementing or complementing

84. U.S. CONST. art. VI.

85. Under U.S. law, a self-executing treaty is one that is directly enforceable in U.S. courts without the need for implementing legislation. See Foster v. Neilson, 27 U.S. 253, 314 (1829). More recently, in Medellin, the U.S. Supreme Court stated: "What we mean by 'self-executing' is that the treaty has automatic domestic effect as federal law upon ratification.” Medellín v. Texas, 552 U.S. 491, 505 n.2 (2008). For a good discussion of the self-executing treaty doctrine, see generally Carlos Manuel Vasquez, The Four Doctrines of Self-Executing Treaties, 89 AM. J. INT'L L. 695 (1995).

86. Medellin, 552 U.S. at 506, n.4.

87. See, e.g., Cornejo v. County of San Diego, 504 F.3d 853, 856 (9th Cir. 2007); Gandara v. Bennett, 528 F.3d 823, 828 (11th Cir. 2008).

88. S. Exec. Rep. No. 91-9, at 5 (1969) (containing the transcript of the hearings on the VCCR as an Appendix). 
legislation." ${ }^{89}$ The Senate gave its advice and consent to the treaty with that understanding. ${ }^{90}$ Thus, a strong case can be made for the self-executing nature of the treaty.

If, however, the VCCR is not self-executing, it cannot be enforced in U.S. courts absent implementing legislation, which Congress has never passed (perhaps because it viewed the VCCR as self-executing). Even if the entire VCCR is not self-executing, it is possible for the courts to determine that select provisions, such as Articles 36 and 37, are selfexecuting. ${ }^{91}$ For example, in Sei Fujii, the California Supreme Court stated that some provisions of the United Nations Charter may be self-executing, even though the particular provisions relied upon by the plaintiff in that case were not. $^{92}$ The Court stated: "In determining whether a treaty is selfexecuting courts look to the intent of the signatory parties as manifested by the language of the instrument, and, if the instrument is uncertain, recourse may be had to circumstances surrounding its execution." ${ }^{93}$ If that treaty's language is "clear and definite" or "prescribed in detail the rules governing rights and obligations of individuals," it is likely that the framers intended for that treaty provision to be self-executing. ${ }^{94}$

\section{B. Who May Enforce Consular Notification Rights?}

Assuming that the consular notification provisions of the VCCR are self-executing, it must next be determined who may bring suit to enforce them. The possibilities include the states who are parties to the VCCR, counting the United States, and the individuals whose consular notice rights are violated.

\section{Suits by States Parties}

Some federal circuit courts have denied individuals the ability to bring suit to enforce their consular notification rights on the ground that consular rights belong not to the individual, but to the states who are parties to the

\footnotetext{
89. Id.

90. Id.

91. See Sei Fujii v. State, 242 P.2d 617, 620-21 ( Cal. 1952); see also Vasquez, supra note 85, at 709 ("[I]t is well accepted that some provisions of a treaty may be self-executing while others are not.") (citing RESTATEMENT (THIRD) OF THE FoREIGN RELATIONS LAW OF THE UNITED STATES $\S 111 \mathrm{cmt} . \mathrm{h}$ (1987)).

92. Sei Fujii, 242 P.2d at 621 (citing Curran v. City of New York, 77 N.Y.S.2d 206, 212 (Sup. Ct. 1947)).

93. Id. at 620; see also Saipan v. U.S. Dep't of Interior, 502 F.2d 90, 97 (9th Cir. 1974) (suggesting that contextual factors may be used to determine whether international agreements are selfexecuting).

94. See Sei Fujii, 242 P.2d at 621; see also Jordan J. Paust, Medellin, Avena, The Supremacy of Treaties, and Relevant Executive Authority, 31 SufFOLK TRANSNAT'L L. REV. 301, 328-29 (2008).
} 
VCCR. ${ }^{95}$ However, it is difficult for foreign governments to sue U.S. states in federal court for noncompliance with the VCCR due to the Eleventh Amendment to the United States Constitution, which provides states with immunity from suit in federal court in most circumstances. ${ }^{96}$ One possibility that has been suggested is that foreign states can sue for injunctive relief, which is permitted by the Eleventh Amendment. ${ }^{97}$ However, such relief would only apply prospectively and it is unclear how it would be monitored or enforced against the U.S. states. It also is unclear whether U.S. courts would entertain suits by foreign states against the United States in U.S. federal courts due to jurisprudential doctrines such as the political question doctrine ${ }^{98}$ and the Act of State doctrine. ${ }^{99}$ Accordingly, absent federal legislation abrogating state sovereign immunity under the Eleventh Amendment, it is likely that the U.S. government is obligated to bring suit on behalf of foreign governments to enforce the VCCR. ${ }^{100}$

The federal government could choose a few select cases where it appeared that the failure of a state or local authority to provide timely consular notification made a difference and bring suit to raise awareness of the issue and force state compliance. Suits by the federal government to enforce consular notification rights would certainly demonstrate that the U.S. government takes its treaty obligations seriously.

Alternatively, the U.S. Congress could also step in and enact legislation making it crystal clear that the VCCR (or at least Articles 36 and 37 dealing with consular notification rights) is self-executing. ${ }^{101}$ By legislation, Congress can create a cause of action and specify appropriate

95. See, e.g., Mora v. New York, 524 F.3d 183, 194-97 (2d Cir. 2008). The reasoning of these lower court decisions is discussed in more detail below.

96. U.S. CONST. amend. XI; see also William J. Aceves, The Vienna Convention on Consular Relations: A Study of Rights, Wrongs and Remedies, 31 VAND. J. TRANSNAT'L L. 257, 282-88 (1998).

97. Anthony S. Winer, Escape from the Medellin Maze, 25 CONN. J. INT'L L. 331, 372 (2010).

98. See, e.g., Baker v Carr, 369 U.S. 186, 211-12 (1962) (stating that questions involving foreign relations are often, but not always, considered political questions beyond judicial cognizance.)

99. See Banco Nacional de Cuba v. Sabbatino, 376 U.S. 398, 416 (1964) ("Every sovereign state is bound to respect the independence of every other sovereign state, and the courts of one country will not sit in judgment on the acts of the government of another, done within its own territory. Redress of grievances by reason of such acts must be obtained through the means open to be availed of by sovereign powers as between themselves"); see also Aceves, supra note 96, at 298-306.

100. See Aceves, supra note 96, at 317; see also Mora, 524 F.3d at 197-98.

101. See Medellín v. Texas, 552 U.S. 491, 520, 526 (2008) (appearing to invite Congress to take a more active role with respect to treaty implementation). 
plaintiffs, whether those are individual foreign nationals or their states. ${ }^{102}$ Congress also could specify an appropriate remedy for any violation. ${ }^{103}$

\section{Suits by Individuals}

Absent action by the United States federal government, however, the question remains whether the VCCR creates a private or individual cause of action for foreign nationals whose consular notification rights have been violated. Several courts, including the U.S. Supreme Court, have assumed without deciding that Article 36 does create individually enforceable rights. ${ }^{104}$ At least four Supreme Court justices have expressly stated that they would find an individual cause of action for a VCCR Article 36 violation, but the majority has not reached the issue on the merits. ${ }^{105}$

Some lower courts that have considered the issue on the merits have held that Article 36 of the VCCR does create individually enforceable rights. ${ }^{106}$ These courts rely primarily on the plain language of Article 36 itself, which speaks in terms of a foreign national's "rights" of consular notification. ${ }^{107}$ This focus on the treaty's text is consistent with the test for self-executing treaty provisions, discussed in the Sei Fujii case above, as well as with the general rules of treaty interpretation under international law. According to Article 31 of the Vienna Convention on the Law of Treaties, the first rule of treaty interpretation is to ascertain the ordinary meaning of a word or phrase in context and in light of the object and purpose of the treaty. ${ }^{108}$ One common definition of the word "right" is a "legally enforceable claim." ${ }^{109}$ Interpreting the treaty to allow consular notification rights to be legally enforceable in domestic courts also furthers the object and purpose of the treaty, which is to allow consular officers to provide protection for their nationals abroad. If such claims are not enforceable in court, there may be less incentive for law enforcement

102. Such citizen suit provisions are increasingly common in other federal statutes. See, e.g., Clean Water Act, 33 U.S.C. § 1365 (2010); Clean Air Act, 42 U.S.C. § 7604 (2010); Americans with Disabilities Act, 42 U.S.C. $§ 12133$ (2010); Fair Housing Amendments Act, 42 U.S.C. $§ 3613$ (2010).

103. Remedies for violation of the VCCR are discussed in more detail in Part VI infra.

104. See Sanchez-Llamas v. Oregon, 548 U.S. 331, 343 (2006); Medellín, 552 U.S. at 506 n.4; United States v. Emuegbunam, 268 F.3d 377, 390 (6th Cir. 2001); United States v. Esparza-Ponce, 7 F.Supp.2d 1084, 1096 (S.D. Cal. 1998).

105. See, e.g., Sanchez-Llamas, 548 U.S. at 374, 378 (Breyer, J., dissenting).

106. See, e.g., Jogi v. Voges, 480 F.3d 822, 834 (7th Cir. 2007); United States v. Briscoe, 69 F.Supp.2d 738, 745 (D.V.I. 1999), aff'd 234 F.3d 1266 (3d Cir. 2000).

107. VCCR, supra note 2, at art. 36(1)(b) ("The said authorities shall inform the person concerned without delay of his rights under this subparagraph.").

108. Vienna Convention on the Law of Treaties art. 31, May 23, 1969, 1155 U.N.T.S. 331 [hereinafter VCLT].

109. See, e.g., BLACK's LAW DiCTIONARY 1189 (5th ed. 1979). 
authorities to comply with the requirements of consular notification or to obtain redress for a violation.

A secondary method of treaty interpretation is to consider the intent of the drafters as evidenced by the travaux preparatoires (preparatory work). ${ }^{110}$ There are several statements in the negotiating and drafting history of the VCCR that suggest that the drafters thought of the right of consular notification as an important individual right that should be enforceable. ${ }^{111}$ For example, during the International Law Commission's preparation of the draft of the Vienna Convention, Mr. Edmunds of the United States described the right of consular access as "a fundamental human right" ${ }^{112}$ and summed up the importance of that right as follows:

[T]he protection of human rights by consuls in respect of their nationals should be the primary consideration for the [International Law] Commission. The fact that, under the laws of some States, it was possible to isolate an accused person from his own lawyer was all the more a reason to safeguard the right of his consul to visit him. In many respects, to a person who was often ignorant of the local language and laws, a visit by his consul was more important than that of a lawyer. ${ }^{113}$

Several delegates to the United Nations conference on the VCCR also described consular notification as a right of the individual ${ }^{114}$ that is

110. See VCLT, supra note 108, at art. 32; see also Sei Fujii v. State, 242 P.2d 617, 622 (Cal. 1952).

111. See, e.g., Summary Records of the 587th Meeting, [1961] 1 Y.B. Int'1 L. Comm'n 33, U.N. Doc. A/CN.4/SER.A/1961 (Statement by Mr. Edmonds).

112. Id.

113. Summary Records of the 534th Meeting, [1960] 1 Y.B. Int'l L. Comm'n 47, U.N. Doc. A/CN.4/SER.A/1960 (Statement by Mr. Edmonds). Some delegates agreed with Mr. Edmonds that the issue should be viewed as one of human rights (see Statement by Mr. Bartos of Yugoslavia, id. at 46), but others suggested that the issue was solely about the ability of consular officers to assist their nationals, see Summary Records of the 535th Meeting, [1960] 1 Y.B. Int'1 L. Comm'n 48-49, U.N. Doc. A/CN.4/SER.A/1960 (Statement by Mr. Fitzmaurice)).

114. United Nations Conference on Consular Relations, Mar. 4-Apr. 22, 1963, Twelfth plenary meeting, ๆ 33, U.N. Doc. A/CONF.25/16.ADD.1 (Apr. 17, 1963) (Statement by Mr. Spyridakis, Greece) ("The purpose of the obligation imposed on the authorities of the receiving State . . . was to establish an additional safeguard for the rights of the individual and to reinforce the ideal of humanism.”); see also id. at Second Committee - Fifth Meeting, I 34 (Mar. 7 1963) (Statement by Mr. Woodberry, Australia) and 936 (statement by Mr. Perez Hernandez, Spain); Second Committee Seventeenth Meeting, I 11 (Mar. 15, 1963) (Statement by Mr. Chin, Korea); Second Committee Eighteenth Meeting, ๆ 33 (Mar. 18, 1963) (Statement by Mr. Bouziri, Tunisia). 
"fundamental,"115 "indispensible,"116 "sacred,"117 and is a human right within the scope of the Universal Declaration of Human Rights. ${ }^{118}$

Despite this evidence of the self-executing nature of consular notification rights, the majority of federal circuit courts that have addressed the issue thus far have declined to hold that Article 36 of the VCCR creates individually enforceable rights. For example, the Fifth, ${ }^{119}$ Sixth, ${ }^{120}$ Ninth $^{121}$ and Eleventh ${ }^{122}$ Circuit Courts have all rejected the idea that Article 36 of the VCCR creates an individually enforceable right, finding instead that the primary purpose of the VCCR is to facilitate the exercise of consular functions, not to benefit individuals. In so holding, these courts have relied largely on language in the VCCR's preamble stating that the purpose of consular privileges and immunities is not to benefit individuals. ${ }^{123}$ This language must be understood in context. The context suggests that the language was intended was to make clear that consular officers should not abuse their privileges and immunities provided by the treaty because those privileges and immunities existed to facilitate the officers' work, not to allow the officers to flaunt the laws of the host country. ${ }^{124}$ There is no evidence to suggest that this preambular language was included to undermine the fundamental right of foreign nationals to consular notification. Moreover, reliance on the text of Article 36 itself is the first rule of treaty interpretation and the context provided by the preamble is only a secondary method of ascertaining the meaning of a treaty provision. ${ }^{125}$ Hence, the language of the preamble should not be allowed to control the unambiguous language of the specific article at issue.

Some courts have also sought evidence of the practices of other states that are parties to the VCCR, ${ }^{126}$ which has tended to show that the majority of states parties do not provide for an individual cause of action for a violation of consular notification rights. However, that state practice may

115. Second Committee - Fifth Meeting, 934 (Statement by Mr. Woodberry (Australia)).

116. Second Committee - Seventeenth Meeting, \11(Statement by Mr. Chin (Korea)).

117. Second Committee - Fifth Meeting, ๆ 36 (statement by Mr. Perez Hernandez (Spain)).

118. Id. at 47 (statement by Mr. Alvarado Garaicoa (Ecuador)).

119. United States v. Jimenez-Nava, 243 F.3d 192, 198 (5th Cir. 2001).

120. United States v. Emuegbunam, 268 F.3d 377, 391 (6th Cir. 2001).

121. Cornejo v. County of San Diego, 504 F.3d 853 (9th Cir. 2007).

122. Bennett v. Gandara, 528 F.3d 823 (11th Cir. 2008).

123. See, e.g., Emuegbunam, 268 F.3d at 391.

124. Jogi v. Voges, 480 F.3d 822, 833 (7th Cir. 2007); Bennet v. Gandara, 528 F.3d at 836-37 (Rodgers, J., specially concurring). But see Mora v. New York, 524 F.3d 183, 196-97 (2nd Cir. 2008) (acknowledging disagreement, but finding that primary purpose of treaty is to established rights and relations between States and not between an individual and a State).

125. See VCLT, supra note 108 , at art. $31,32$.

126. Mora, 524 F.3d at 197 n.22. 
be changing. For example, in 2006, the Federal Constitutional Court in Germany held that failure to provide consular notification under Article 36 of the VCCR violates the guarantee of a fair trial under the German Constitution. ${ }^{127}$ Also, dozens of countries have filed amicus briefs in VCCR litigation arguing that an individual cause of action is created by Article 36 of the VCCR. ${ }^{128}$ The ICJ endorsed this view in LaGrand ${ }^{129}$ and Avena. ${ }^{130}$ Likewise, the Inter-American Commission on Human Rights has held that consular notification rights under the VCCR are human rights that are part of the concept of due process in international human rights treaties. $^{131}$ Thus, the balance of the international authority appears to conclude that Article 36 of the VCCR does create an individual cause of action. That international opinion is relevant under treaty interpretation rules and under the self-executing treaty doctrine because it indicates the understanding of the signatory parties as to the meaning of the treaty. ${ }^{132}$

\section{WHAT DOES CONSULAR NOTIFICATION "WITHOUT DELAY" MEAN?}

VCCR Article 36(b) requires that notice of consular rights and notification to the consulate occur "without delay." ${ }^{133}$ The issue of how quickly consular notification must take place presented significant difficulties during the negotiation of the VCCR and continues to be litigated to this day.

127. Klaus Ferdinand Garditz, International Decisions: Case Nos. 2 BvR 2115/01, 2 BvR 2132/01, \& 2 BvR 348/03 [Vienna Consular Relations Case], 101 AM. J. INT'L L. 627, 629, 632 (2007).

128. See Brief for Government of the United Mexican States as Amicus Curiae Supporting Petitioner at 21, Sanchez-Llamas v. Oregon, 548 U.S. 331 (2006) (No. 04-10566), 2005 WL 3543087; Brief for Republic of Honduras and Other Foreign Sovereigns as Amici Curiae Supporting Petitioners at 25, Sanchez-Llamas, 548 U.S. 331; Brief for European Union and Members of the International Community as Amici Curiae Supporting Petitioners at 7, Sanchez-Llamas, 548 U.S. 331.

129. F.R.G. v. United States (LaGrand Case), 2001 I.C.J. 446, 449 (Jun. 21, 2001).

130. Mexico v. United States (Case Concerning Avena and Other Mexican Nationals), 2004 I.C.J. 12, 36, 65-66, 70-72.

131. The Right to Information on Consular Assistance in the Framework on the Guarantees of the Due Process of Law, Advisory Opinion OC-16/99, Inter-Am. Ct. H.R. (ser. A), No. 16 甲 84, 124 (Oct. 1, 1999).

132. See VCLT, supra note 108, at art. 36. As an alternative to reliance on the VCCR, Professor William Carter has suggested that an individual might bring a mandamus action requesting a judicial order that the government comply with its duty to implement the VCCR. William M. Carter, Jr., Treaties as Law and the Rule of Law: The Judicial Power to Compel Domestic Treaty Implementation, 69 MD. L. REV. 344 passim (2010). However, Professor Carter himself identifies several procedural and substantive limitations with respect to this proposal, including that it would not provide individual relief in particular cases. Id. at 347-48, 379 .

133. VCLT, supra note 108, at art. 36(b). 
During the convention negotiations, Sir Gerald Fitzmaurice from the United Kingdom of Great Britain and Northern Ireland proposed the first draft of a new article on consular notification (provisionally numbered Article 30A) to the International Law Commission in May 1960. The original draft article stated that "the local authorities shall inform the consul of the sending State without delay" of the detention of a foreign national and that "communications from [a foreign] national shall immediately be forwarded by the local authorities." 134 Several delegates supported this proposal. ${ }^{135}$ However, Mr. Matine-Daftary of Iran objected on the grounds that it is not always possible to discover the identity or nationality of a person who has been detained, and it would therefore be wrong to impose upon the local authorities an obligation to inform consuls immediately and automatically. ${ }^{136}$ Mr. Yokota of Japan agreed, and suggested that there might, in addition, be conflicts with the penal codes of many countries. ${ }^{137}$ $\mathrm{He}$ suggested the insertion of the word "undue" before "delay," a suggestion that the ILC subsequently adopted in a later draft. ${ }^{138}$ The United States and the United Kingdom expressed concern that the word "undue" was "susceptible to considerable abuse" and proposed its deletion. ${ }^{139} \mathrm{Mr}$. Erim of Turkey suggested that notification occur "within a reasonable time." ${ }^{140}$ There also was some discussion of whether a time frame should be included, i.e., notice must be given within a certain number of hours or days of arrest. ${ }^{141}$ Several parties appeared concerned about committing to a specific timeframe in all circumstances. In light of these objections, it was ultimately agreed to revert back to the "without delay" language with no

134. Summary Records of the 534th Meeting, supra note 113, at 42.

135. Id. at $42-43$ (statements by Mr. Hsu (China), Mr. Edmonds (United States), Mr. Verdross (Austria), Mr. Sandstrom (Sweden), Mr. Scelle (France), and Mr. Ago (Italy)).

136. Id. at 42 .

137. Id. at 43. Mr. Tunkin from the U.S.S.R. also argued strongly for inclusion of a reference to local laws, stating that for national security reasons, consuls might not be allowed access to certain areas. $I d$. at 44 .

138. See Report of the Int'l Law Comm'n Covering the Work of its Twelfth Session, 25 April-1 July 1960, art. 6, U.N. Doc. A/4425 (1960), reprinted in [1960] 2 Y.B. Int'l L. Comm'n 151-52, U.N. Doc. A/CN.4/SER.A/1960/Add.1 [hereinafter 1960 Draft Article 6]. In earlier drafts and meetings, article 6 was referred to as additional article 30A. See Summary Records of the 586th Meeting, [1961] 1 Y.B. Int'1 L. Comm'n 32, note a, U.N. Doc. A/CN.4/SER.A/1961.

139. See Report of the United States Delegation, supra note 58, at 59.

140. See Summary Records of the 536th Meeting, supra note 61 at 55.

141. Suggestions for the timeframe in which consular notice should be given varied widely. For example, the representative from the Netherlands suggested that notice must be given within one month at the latest. See Summary Records of the 587th Meeting, supra note 111, at 33. By contrast, Mr. Edmonds from the United States suggested that a foreign national should not be detained incommunicado for more than 48-72 hours. See, e.g., Summary Records of the 586th Meeting, supra note 138 , at 32 . 
specific time frame in which notification must occur. ${ }^{142}$ Thus, it has been left to the courts to interpret the meaning of that phrase in the context of particular cases.

\section{A. Interpretation by the International Court of Justice}

Somewhat surprisingly, given the inherent ambiguity of the phrase "without delay," not many courts have considered the meaning of those words in specific factual contexts. The ICJ did have such an opportunity in Avena, where it held that notice by Texan officials to the Mexican consulate five days (three business days) after arresting a Mexican national, Mr. Hernández, was sufficient within the meaning of VCCR Article 36(1)(b). However, the ICJ found that Texas breached its independent obligation to notify Mr. Hernández about his right to consular notification without delay in the first instance. ${ }^{143}$

\section{B. Interpretation of "Without Delay" by U.S. Authorities}

The U.S. Supreme Court has not addressed the issue of how soon after arrest and detention consular notification must be given. Few other U.S. courts have had the opportunity to address the issue either. Those courts that have considered the issue on the merits have reached somewhat inconsistent results. For example, in United States v. Miranda, ${ }^{144}$ a Minnesota court held that failure to notify the Mexican consulate for two days after the arrest of a Mexican national violated the VCCR under the circumstances. By contrast, in Bell v. Virginia,${ }^{145}$ the Virginia Supreme Court held that a thirty-six hour delay prior to notification of the Jamaican consulate of Bell's arrest did not violate Article $36 .{ }^{146}$ But, according to the Eighth Circuit Court of Appeals, a four-day delay was too long. ${ }^{147}$

In an instruction manual for law enforcement officers, the U.S. State Department currently takes the following position with respect to the timing of consular notification: "[T]here should be no deliberate delay, and that notification must occur as soon as reasonably possible under the

142. VCCR, supra note 2, at art. 36

143. Mexico v. United States (Case Concerning Avena and Other Mexican Nationals), 2004 I.C.J. 12, 52, 54 (Mar. 31, 2004).

144. 65 F.Supp.2d 1002, 1005 (D. Minn. 1999) ("The Court finds that a period of two days constitutes a 'delay' within the meaning of the Convention when, as in this case, the record is devoid of evidence demonstrating that earlier notification would not have been reasonably possible.”).

145. 563 S.E.2d 695, 706 (Va. 2002).

146. A federal district court upheld this ruling in a related action for a writ of habeas corpus. Bell v. True, 413 F.Supp.2d 657, 728 (W.D. Va. 2006).

147. United States v. Santos, 235 F.3d 1105 (8th Cir. 2000) (no dispute that four-day delay violated VCCR). 
circumstances .... Ordinarily, [the officer] must inform a foreign national of the possibility of consular notification by or at the time the foreign national is booked for detention." ${ }^{148}$ In a later portion of the manual, the Department of State "recommends that notification [to the consular officer] be given within 24 to 72 hours of arrest or detention." 149

Some states within the United States have begun to address the issue legislatively. Thus far, only California has enacted a statute to further define the duty of consular notification. That statute provides that a foreign defendant must be given consular notification within two hours of arrest. ${ }^{150}$ While not a legislative act, the Texas Attorney General has issued a Magistrate's Guide to Consular Notification under the VCCR which provides that magistrate judges should determine the citizenship of persons appearing before them on the record and offer consular notification without delay if the person is not a U.S. citizen. ${ }^{151}$ The state of Oregon requires by statute that all police officers are trained to understand the requirements of the VCCR and identify situations in which the officers are required to provide consular notification. ${ }^{152}$ Legislation also has been proposed in Illinois that would require notification by the detaining authority within forty-eight hours of booking or detention and requires judges to ensure that a foreign defendant has received consular notification at the first appearance in court. ${ }^{153}$

\section{IF CONSULAR NOTIFICATION WAS NOT GIVEN "WITHOUT DELAY" AND THE FAILURE IS DISCOVERED AFTER TRIAL, HOW CAN THE ISSUE BE RESOLVED ON APPEAL?}

In both Medellin and Sanchez-Llamas, the foreign defendants were unsuccessful in their appeals based on lack of consular notification because

148. See U.S. Dept. of State, Consular Notification AND Access 21 (2010), http://travel.state.gov/consul_notify.html.

149. Id. at 25 .

150. CAL. Penal CODE $\S 834 \mathrm{c}(\mathrm{a})(1)$ (2011) provides: "In accordance with federal law and the provisions of this section, every peace officer, upon arrest and booking or detention for more than two hours of a known or suspected foreign national shall advise the foreign national" of his or her consular notification rights. California law also provides that California law enforcement agencies shall ensure that policy or procedure and training manuals incorporate language based on the Vienna Convention. CAL. Penal Code $\S 843$ c(c) (2006).

151. Magistrate's Guide to Consular Notification under the Vienna Convention 9, www.oag.state.tx.us/criminal/consular.shtml.

152. OR. REV. STAT. § 181.642(2) (2010).

153. Gen. Assemb. S.B. 1906, $97^{\text {th }}$ Gen. Assemb. (Ill. 2011). Florida, by contrast, has enacted a statute stating that failure to provide consular notification shall not be a defense in any criminal proceeding and shall not be a cause of discharge from custody. Fla. Stat. Ann. § 901.26 (West 2010). 
they did not raise the issue at trial. ${ }^{154}$ In both cases, the lower courts held and the U.S. Supreme Court affirmed, that state procedural default rules prevent a defendant from raising the issue for the first time on appeal. ${ }^{155}$ Many foreign defendants do not raise the issue of lack of consular notification in a timely manner because they do not know they possess such a right. However, assuming that the law in this regard will not change in the near future, how can foreign defendants raise the issue of lack of consular notification outside of a direct appeal? Some lower court cases suggest that an individual may be able to bring a claim for relief by way of a suit under the Sixth Amendment to the U.S. Constitution for ineffective assistance of counsel, a suit under the Fifth Amendment's due process clause, or a suit under other federal laws such as the Alien Tort Statute. ${ }^{156}$

\section{A. Sixth Amendment Ineffective Assistance of Counsel}

Foreign defendants who were denied their consular notification rights have had some success raising the issue on appeal of their conviction or sentence on the grounds that their attorneys were constitutionally ineffective for not being aware that their clients had such rights and not ensuring communication with the appropriate consulate. For example, this strategy was successfully used in Osageide v. United States. ${ }^{157}$ In that case, the Seventh Circuit granted a Nigerian defendant's motion for postconviction relief on the grounds of ineffective assistance of counsel where the defense attorney failed to invoke the defendant's right to consular access. The court stated that consular assistance could have made a difference because the consulate may have been able to help secure witnesses to identify voices on a key piece of recorded evidence. The appellate court remanded the case to the lower court for an evidentiary hearing to determine what assistance the Nigerian consulate would have provided.

Another example is Valdez v. State, ${ }^{158}$ where the court-appointed attorney for a Mexican national convicted of murder was found ineffective because he failed in his duty to inform the defendant of his right to communicate with the consulate. When the Mexican consulate was notified

154. Medellin v. Texas, 552 U.S. 491, 498 (2008); Oregon v. Sanchez-Llamas, 548 U.S. 331, 35556.

155. Procedural default rules require that issues be raised in a timely manner. Failure to do so generally results in forfeiture of the claim. See Sanchez-Llamas, 548 U.S. at 356 ("Procedural default rules are designed to encourage the parties to raise their claims promptly and to vindicate the law's important interest in the finality of judgments.").

156. 28 U.S.C. $\$ 1350$ (2010); see also e.g., Jogi v. Voges, 480 F.3d 822 (7th Cir. 2007).

157. 543 F.3d 399 (7th Cir. 2008).

158. 46 P.3d 703 (Okla. Crim. App. 2002). 
by a relative that Mr. Valdez had been sentenced to death, the Mexican consulate retained experts and experienced attorneys who investigated $\mathrm{Mr}$. Valdez's background and learned that he suffered from organic brain damage, which greatly contributed to and altered his behavior. The Oklahoma Court of Criminal Appeals held that the lack of consular notification resulted in a miscarriage of justice and granted Mr. Valdez's motion for re-sentencing.

If reliance is placed on the Sixth Amendment right to effective counsel, a secondary question that arises is: what standard for prejudice should be used? Outside of the consular notification cases, the Strickland $v$. Washington $^{159}$ test is normally used to determine whether an attorney was so ineffective as to constitute a violation of the U.S. Constitution. In Strickland, the U.S. Supreme Court held that there are two components to a successful claim of ineffective assistance of counsel under the Sixth Amendment: "First, the defendant must show that counsel's performance was deficient... Second, the defendant must show that the deficient performance prejudiced the defense. This requires showing that counsel's errors were so serious as to deprive the defendant of a fair trial, a trial whose result is reliable." ${ }^{160}$ The Court further held that prejudice is presumed in certain contexts, including various kinds of state interference with counsel's assistance. ${ }^{161}$ In such cases, the Court reasoned that "such circumstances involve impairments of the Sixth Amendment right that are easy to identify and, for that reason and because the prosecution is directly responsible, easy for the government to prevent." ${ }^{162}$

A similar kind of logic may be applied to claims of lack of consular notification. Article 36(1)(b) of the VCCR states that it is the duty of the receiving state's authorities to notify foreign nationals who are arrested or detained of their right to have their consulate contacted and, if the foreign national so requests, to notify the appropriate foreign consulate of the arrest or detention. ${ }^{163}$ In most of the consular notification litigation, including Avena, there is no dispute that the authorities failed to provide this consular notification. Thus, the state is directly responsible for creating an easily identifiable and remediable problem that may cause prejudice to the foreign defendants. The state also has the power to prevent such problems in the future by better training its officials and by assigning consequences for the

\footnotetext{
159. Strickland v. Washington, 466 U.S. 668 (1984).

160. Id. at 687 .

161. See id. at 692 .

162. Id.

163. VCCR, supra note 2, at art. 36(1)(b).
} 
failure to provide the notification. ${ }^{164}$ Accordingly, there is a basis for the courts to apply the same presumption used in Sixth Amendment ineffective assistance of counsel cases where the government is at fault to cases involving violation of consular notification rights under the VCCR.

Alternatively, with respect to other ineffectiveness claims alleging a deficiency in attorney performance not involving state misconduct, the Strickland Court held that a "defendant need not show that counsel's deficient conduct more likely than not altered the outcome in the case."165 Rather, "[t]he defendant must show that there is a reasonable probability that, but for counsel's unprofessional errors, the result of the proceeding would have been different." ${ }^{166}$ Accordingly, under this alternative standard, a foreign national who alleges lack of consular notification would have to show a reasonable probability that, had the foreign national known of such rights, he or she would have requested and received consular assistance of a specific type which, in turn, would have had a reasonable probability to make a difference in the outcome of the case. Neither the courts nor the U.S. State Department has taken the position that "prejudice" means that the case would have ended in an acquittal instead of a conviction. Instead, a defendant might be able to show that with consular assistance, additional evidence might have been uncovered that could have mitigated sentencing. ${ }^{167}$ The Seventh Circuit recently used the Strickland test to assess prejudice in a consular notification case, becoming the first federal circuit court expressly to do so. ${ }^{168}$

\section{B. Fifth Amendment Due Process Requirement of Fundamental Fairness}

Some courts have relied instead on the Fifth Amendment to the U.S. Constitution $^{169}$ in holding that a proceeding must be fundamentally fair in order to comport with the requirements of due process. Under this line of reasoning, the failure to provide consular notification may constitute a

164. This is the approach taken in Gen. Assemb., S.B. 1906, 97 $7^{\text {th }}$ Gen. Assemb. (Ill. 2011) (requiring that the judge grant a reasonable request for a stay in any case where consular notice was not provided at the time of arrest or detention to allow for contact to be made with the consulate).

165. Strickland, 466 U.S. at 693.

166. Id. at 694 .

167. See e.g., Valdez v. State, 46 P.3d 703 (Okla. Crim. App. 2002) (describing evidence unearthed by Mexican authorities that the defendant suffered from severe organic brain damage which led the Oklahoma Court of Criminal Appeals to order that Valdez's capital sentence be reconsidered).

168. Sandoval v. United States, 574 F.3d 847, 851 (7th Cir. 2009). The Second Circuit applied a similar standard in United States v. De La Pava, 268 F.3d 157, 165-66 (2d Cir. 2001).

169. U.S. CONST. amend. V. See, e.g., United States v. Mendoza-Lopez, 481 U.S. 828 (1987). 
procedural defect that renders the proceeding fundamentally unfair and thus unconstitutional. $^{170}$

This approach resulted in a slightly different test for prejudice, which was first articulated in Rangel-Gonzales ${ }^{171}$ and later refined in VillaFabela. ${ }^{172}$ To establish prejudice pursuant to this test, a defendant must show that: (1) he did not know of his right; (2) he would have availed himself of the right had he known of it; and (3) there was a likelihood that contact with the consulate would have resulted in assistance to him. ${ }^{173}$ In Rangel-Gonzales, the defendant met this burden of proof by providing an affidavit in which he stated that he did not know he had a right to contact the Mexican consulate and that he would have done so if he had known. ${ }^{174}$ He also obtained an affidavit from the Mexican Consul General in Seattle stating that his office would assist a Mexican national who called for help by contacting friends and an attorney and perhaps by sending a consular officer to the legal proceedings. ${ }^{175}$

It may be argued that this standard for prejudice is too low-that virtually every case involving lack of consular notification would meet it because all the defendant would have to do is plead ignorance and obtain a statement from the consulate that it would have provided help if asked. However, the Villa-Fabela case proves this theory wrong. ${ }^{176}$ There, the court found that even if the defendant had availed himself of his right to consular notification, there was nothing the consulate could have done that would have assisted him in avoiding deportation under the applicable law. ${ }^{177}$ But, if there is a concern that this standard is too low, the more rigorous Sixth Amendment standard for prejudice outlined above could be required.

170. United States v. Villa-Fabela, 882 F.2d 434, 440 (9th Cir. 1989). See also United States v. Ademaj, 170 F.3d 58, 66-67 (1st Cir. 1999).

171. United States v. Rangel-Gonzales, 617 F.2d 529, 530, 531 (9th Cir. 1980).

172. Villa-Fabela, 882 F.2d at 440. While both Villa-Fabela and Rangel-Gonzales are from the Ninth Circuit, this standard has been widely used in other circuits as well. See, e.g., United States v. Raven, 103 F.Supp.2d 38, 41 (D. Mass. 2000); State v. Lopez, 633 N.W.2d 783-84 (Iowa 2001); Torres v. State, 120 P.3d 1186-90 (Okla. Crim. App. 2005).

173. Villa-Fabela, 882 F.2d at 440.

174. Rangel-Gonzales, 617 F.2d at 531.

175. See id.

176. Villa-Fabela, 882 F.2d at 440.

177. Id. Mr. Villa-Fabela was convicted of the crime of re-entry after a prior deportation. Because the INA bars any relief from deportation for this crime, the court determined that the failure to provide consular notice under the circumstances caused no prejudice. 


\section{Alien Tort Statute}

Another argument that has been made in some cases is that failure to provide consular notification rights constitutes a tort in violation of the law of nations within the meaning of the Alien Tort Statute ("ATS"). ${ }^{178}$ This possibility was raised in Jogi v. Voges. ${ }^{179}$ The Seventh Circuit initially decided that such a claim could be made under the ATS, but later withdrew that opinion and substituted a second opinion allowing jurisdiction to rest on the general federal question statute instead. ${ }^{180}$ The Seventh Circuit expressly left open the question of whether jurisdiction could be founded on the ATS for a claimed violation of Article 36 of the VCCR. ${ }^{181}$

To date, no other federal court has upheld a claim that a failure to provide consular notification constitutes a tort within the meaning of the ATS, although the Eleventh Circuit recently remanded a case to the district court to consider the possibility of a valid ATS claim in Sairras $v$. Schleffer. ${ }^{182}$ However, those lower federal courts that have denied these claims appear to have done so on the erroneous basis that the ATS does not independently create a cause of action.

For example, a federal district court in Pennsylvania denied the ATS claim of an Indian national who had not been provided his consular notification rights. ${ }^{183}$ The Pennsylvania court stated that the ATS does not create an individual cause of action; thus, the cause of action must arise from the VCCR itself. It then dismissed the claim on sovereign immunity grounds under the Federal Tort Claims Act without individually analyzing the VCCR claim. Similarly, a federal district court in Tennessee denied a South African's claim under the ATS based on the government's failure to provide consular notification because the district court was bound by the Sixth Circuit's holding in United States v. Emuegbunam ${ }^{184}$ that Article 36 of the VCCR does not create an individual cause of action that may then be raised under the ATS. ${ }^{185}$ Both of these cases are incorrect, however, in light of the U.S. Supreme Court's decision in Sosa v. Alvarez-Machain, ${ }^{186}$ which

178. 28 U.S.C. $§ 1350$ (2010) ("The district courts shall have original jurisdiction of any civil action by an alien for a tort only, committed in violation of the law of nations or a treaty of the United States.").

179. Jogi v. Voges, 480 F.3d 822, 835-36 (7th Cir. 2007).

180. See id. at $824-25$.

181. Id. at 825 ("We can safely leave for another day the question whether the Vienna Convention would directly support a private remedy.").

182. Sairras v. Schleffer, 331 F. App'x. 698, 700-01 (11th Cir. 2009).

183. Bansal v. Russ, 513 F.Supp.2d 264, 280 (E.D. Pa. 2007).

184. 268 F.3d 377, 394 (6th Cir. 2001).

185. Keszthelyi v. Bowman, No. 1:06-CV-187, 2007 WL 626221 (E.D. Tenn. Feb. 23, 2007).

186. Sosa v. Alvarez-Machain, 542 U.S. 692 (2004). 
held that the ATS is not only jurisdictional, but also creates a limited category of claims defined by the law of nations and recognized at common law. ${ }^{187}$ Thus, it is possible for a claim to arise under the ATS if the lack of consular notification constitutes a tort in violation of the law of nations, even if the VCCR itself does not give rise to a cause of action.

The most recent federal circuit court to address the issue on the merits is the Second Circuit, which held in Mora v. New York ${ }^{188}$ that a foreign defendant cannot bring a claim for damages for violation of his consular notification rights under VCCR Article 36 claim pursuant to the ATS. The court held that the defendant had not established a tortious violation of a customary international law that is specific and well-accepted, the test for ATS claims articulated by the Supreme Court in Sosa. ${ }^{189}$

The Second Circuit's holding is open to question, however. In Sosa, the U.S. Supreme Court specifically identified "violations of safe conducts" and "infringements of the rights of ambassadors" as the types of wellaccepted customary international law claims that are cognizable under the ATS. ${ }^{190}$ Consular rights are very closely related to the rights of ambassadors and share much the same pedigree. The two treaties were considered sister conventions ${ }^{191}$ and arose as part of a series of conferences convened by the United Nations General Assembly in the 1950s and the 1960s to encourage the progressive development and codification of international law. ${ }^{192}$ The two Vienna Conventions on Diplomatic and Consular Relations, respectively, were negotiated simultaneously and concluded and signed within a short time of one another. ${ }^{193}$ The connection between diplomatic and consular functions also is amply demonstrated by the fact that there is a "near universal practice of amalgamating consular and diplomatic services" 194 and the VCCR permits officers to perform both types of functions. ${ }^{195}$ Because of this long-standing and close relationship between diplomatic and consular rights, a strong argument could be made

187. This argument was the basis for the Eleventh Circuit's remand in Sairras. See Sairras, 331 F. App'x at 700-01.

188. 524 F.3d 183, 288 (2d Cir. 2008).

189. Sosa, 542 U.S. at 732.

190. Id. at 715,720 .

191. Luke T. Lee, VienNA CONVENTION ON CONSUlAR RELATIONS 15 (1966).

192. United Nations Conference on Consular Relations, Mar. 4-Apr. 22, 1963, Summary records of the first plenary meeting, $\uparrow$ 4, U.N. Doc. A/CONF.25/16.ADD.1 (Mar. 4, 1963) (statement by Acting President Stavropoulos).

193. The Vienna Convention on Diplomatic Relations was concluded in 1961, while the Vienna Convention on Consular Relations was concluded in 1963.

194. Lee, supra note 191 , at 80.

195. See VCCR, supra note 2, at art. 70 . 
that claims under the VCCR are the type of specific and well-accepted claims that may be brought under the ATS as well.

\section{Other Possible Legal Bases for Enforcing Consular Notification Rights}

Foreign nationals and states have also sought damages from government officials under the Federal Tort Claims Act ("FTCA") ${ }^{196}$ and 42 U.S.C. $\S 1983$ for violation of their right to consular notification. ${ }^{197}$ The FTCA provides a limited waiver of the federal government's sovereign immunity when its employees are negligent within the scope of their employment. ${ }^{198}$ Thus far, no lower courts have awarded damages under the FTCA in connection with a claimed violation of the VCCR. ${ }^{199}$ However, the U.S. Supreme Court has not yet reached the issues, so an FCTA action may still be viable. ${ }^{200}$

More promising for foreign nationals may be an action based on $\S$ 1983. Section 1983 provides a cause of action to obtain damages or equitable relief to any person within the jurisdiction of the United States for deprivation of any rights, privileges, or immunities secured by the Constitution and the laws. ${ }^{201}$ There is currently a split among the federal circuit courts as to whether a foreign national may maintain a $\S 1983$ action to remedy a violation of a consular notification rights. ${ }^{202}$ In Jogi v. Voges, the Seventh Circuit held that a national of India who was never informed of his consular notification rights could bring an action against law enforcement authorities for damages. ${ }^{203}$ By contrast, both the Ninth and Eleventh Circuits declined to allow $\S 1983$ actions to proceed because they determined that Article 36 of the VCCR did not create an individual "right"

196. 28 U.S.C. $\S \S 1346,2675-2679$ (2010). See Bansal v. Russ, 513 F.Supp.2d 264, 283-85 (E.D Pa. 2007); see also Turkmen v. Ashcroft, 2006 WL 1662663 (E.D.N.Y. 2006).

197. See Gandara v. Bennett, 528 F.3d 823, 825 (11th Cir. 2008); see also Cornejo v. County of San Diego, 504 F.3d 853, 857 (9th Cir. 2007); see also Breard v. Greene, 523 U.S. 371, 378 (1998).

198. 28 U.S.C. $\S 1346(b)(1)(2010)$.

199. In Sobitan v. Glud, 589 F.3d 379, 389 (7th Cir. 2009), the Seventh Circuit Court of Appeals held that an action for damages against a federal employee for violation of the VCCR may not be maintained under the FCTA because the federal government had not waived its sovereign immunity. However, the court suggested that an action for damages may be available against a state employee who had violated the VCCR.

200. In Breard, the Supreme Court rejected Paraguay's attempt to rely on Section 1983 finding that Paraguay was not a "person ... within the jurisdiction of the United States" within the meaning of the statute. Breard, 523 US at 378. However, the Supreme Court did not address whether a foreign national could maintain a claim on this basis.

201. 42 U.S.C. $§ 1983$ (2010); Breard, 523 U.S. at 378.

202. See John T. Parry, A Primer on Treaties and $\S 1983$ After Medellin v. Texas, 13 LEWIS \& CLARK L. REV. 35 (2009) (making a persuasive case for allowing recovery under section 1983 for violations in the VCCR).

203. Jogi v. Voges, 480 F.3d 822, 835-36 (7th Cir. 2007). 
or cause of action - a necessary prerequisite for a claim under $\S 1983$. $^{204}$ The Supreme Court has not yet resolved this circuit split, but the Seventh Circuit's decision in Jogi suggests that $\S 1983$ actions are also still a viable way to enforce consular notification rights.

\section{WHAT IS THE APPROPRIATE REMEDY AND WHY?}

With respect to the appropriate remedy for a failure to provide timely consular notification, Article 36 of the VCCR states that:

The rights referred to in paragraph 1 of this article shall be exercised in conformity with the laws and regulations of the receiving State, subject to the proviso, however, that the said laws and regulations must enable full effect to be given to the purposes for which the rights accorded under this article are intended.

Thus far in addressing remedies under the VCCR, the U.S. Supreme Court has stated that suppression of evidence is not an appropriate remedy, ${ }^{206}$ but has not yet provided guidance as to what would be an acceptable remedy to give Article 36 rights the "full effect" to which they are entitled.

Some lower courts in the United States have rejected other remedies as well, including dismissal of an indictment ${ }^{207}$ and an action for damages. ${ }^{208}$ On the other hand, some lower courts have remanded cases for reconsideration where it appears that consular assistance might have made a difference. ${ }^{209}$ In cases where prejudice is demonstrated, remand of a case on appeal or stay of a pending trial to allow time for the consulate to become involved would appear to be appropriate actions to remedy the violation. ${ }^{210}$

Regardless of whether a remedy is owed to an individual whose consular notification rights are violated, the United States clearly owes a duty to its treaty partners for breach of its international obligations. One of

204. Cornejo v. County of San Diego, 504 F.3d 853, 860 (9th Cir. 2007); Bennett v. Gandara, 528 F.3d 823, 829 (11th Cir. 2008).

205. VCCR, supra note 2, at art. 36(2).

206. Sanchez-Llamas v. Oregon, 548 U.S. 331,4933 (2006) ("Suppression would also be a vastly disproportionate remedy for an Article 36 violation.").

207. United States v. De La Pava, 268 F.3d 157, 165-66 (2d Cir. 2001).

208. Mora v. New York, 524 F.3d 183, 209 (2d Cir. 2008) (plaintiff unsuccessfully sought damages under the Alien Tort Statute); Gandara, 528 F.3d at 829 (plaintiff unsuccessfully sought damages under 42 U.S.C. $\S 1983)$.

209. See, e.g., Osageide v. United States, 543 F.3d 399, 413-14 (7th Cir. 2008); Valdez v. State, 46 P.3d 704, 710-11 (Okla. Crim. App. 2002).

210. See, e.g., Gen. Assemb. S.B. 1906, 97th Gen. Assemb. (Ill. 2011). 
the most fundamental principles in international law is that of pacta sunt servanda-that treaties are binding upon the parties to them and must be observed in good faith. ${ }^{211}$ As noted above, under U.S. law, treaties are part of "the supreme law of the Land; and the Judges in every State shall be bound thereby." ${ }^{212}$ In addition to judges, the executive branch has an obligation to ensure that international agreements are faithfully executed. ${ }^{213}$

In Medellin, the U.S. Supreme Court agreed with the parties that the United States owes an international legal obligation to Mexico as a result of the United States' breach of the VCCR and the Avena judgment. The Court stated: "No one disputes that the Avena decision-a decision that flows from the treaties through which the United States submitted to ICJ jurisdiction with respect to the Vienna Convention disputes - constitutes an international law obligation on the part of the United States." ${ }^{214}$ However, the Supreme Court did not decide, nor did the parties to the Medellin and Avena litigation agree, on what reparation the United States owes to its treaty partners when it breaches its obligations under the VCCR. In past cases such as Breard, LaGrand, and Avena, the United States has offered an apology and a promise to work harder to prevent future violations. ${ }^{215}$ During the Avena litigation, Mexico expressed its dissatisfaction with these remedies, but no agreement was reached between the U.S. and Mexico as to the appropriate reparation for the established treaty violations in Avena. ${ }^{216}$

Some foreign defendants ${ }^{217}$ and scholars ${ }^{218}$ have argued that failure to provide a remedy for a violation of consular notification rights has the potential to render such rights meaningless. If there are no penalties for failure to provide consular notification, law enforcement officials have little incentive to comply.

In Mora, the Second Circuit attempted to respond to the argument that a lack of a remedy makes the right meaningless, providing four reasons

211. See VCLT, supra note 108, at art. 26; see also RESTATEMENT (THIRD) OF FOREIGN RELATIONS LAW at $\S 321 \mathrm{cmt}$. a. (1987).

212. U.S. CONST. art. VI.

213. U.S. CONST. art. II. See also Aceves, supra note 96, at 289.

214. Medellin v. Texas , 552 U.S. 491, 504 (2008). Presumably, then, the United States owes Mexico some form of reparation for the United States' breach of its treaty obligations.

215. See, e.g., Case Concerning Avena and Other Mexican Nationals, 2004 I.C.J. 12, 55-56 (Mar. 31).

216. See Arturo Sarukhan, Why Enforcing the Vienna Convention makes sense, DALLAS MORNING NEWs, May 7, 2008, at 1.

217. See Mora v. New York, 524 F.3d 183, 197-99 (2d Cir. 2008).

218. Cindy Galway Buys, The United States Supreme Court Misses the Mark: Towards Better Implementation of the United States' International Obligations, 24 CONN. J. INT'L L. 39, 64-65 (2008). 
why it believes that a lack of an individual right does not deprive Article 36 of the VCCR of force. ${ }^{219}$ First, states parties can safeguard rights through international negotiations and reclamations. ${ }^{220}$ Second, because the treaty rights and obligations are reciprocal, states have an incentive to comply. Third, the presiding judge may, on his or her own initiative, inquire whether consular notification has been given and, if not, take steps to remedy the situation. Fourth, a detained foreign national could petition the authorities to seek compliance.

With respect to the first point made by the Second Circuit, the court is correct that the duty falls primarily on states parties to the VCCR to safeguard the rights provided therein. ${ }^{221}$ However, when those rights have been shown to be repeatedly ignored, as has been demonstrated in litigation in and against the United States, and negotiations have not resulted in any satisfactory solution, individuals whose rights have been violated should be given an opportunity to seek redress through other means. ${ }^{222}$

The Second Circuit is also correct with respect to its second point that the reciprocal obligations of the treaty provide an incentive for states to comply. In fact, the desire to ensure that U.S. citizens traveling abroad were afforded their consular notification rights was an important reason for President Bush's Memorandum directing the U.S. states to comply with the Avena judgment. However, the U.S. Supreme Court held in Medellin that the President could not unilaterally order the states to comply, thereby leaving the individual foreign defendants without a remedy in the absence of further congressional action. ${ }^{223}$

Third, while it would be laudable for a presiding judge to inquire on his or her own initiative as to whether consular notification has been given, it is likely that many local and state judges are not aware of the requirements of the VCCR. In addition, they may reasonably assume, based on the language of Article 36, that providing such notice is the responsibility of the arresting or detaining officer, not the judge. ${ }^{224}$ To

219. Mora, 524 F.3d at 197-99.

220. See id. at 197 (citing Edye v. Robertson (Head Money Cases), 112 U.S. 580, 598 (1884)).

221. See Head Money Cases, 112 U.S. at 598 ("A treaty is primarily a compact between independent nations. It depends for the enforcement of its provisions on the interest and the honor of the governments which are parties to it.").

222. The U.S. Supreme Court also recognized in the Head Money Cases that "a treaty may also contain provisions which confer certain rights upon the citizens or subjects of one of the nations residing in the territorial limits of the other. ..." Id.

223. Medellin v. Texas, 552 U.S 491, 525-26 (2008).

224. Article 36 of the VCCR provides that notice shall be given without delay upon arrest or detention, not in connection with a later appearance in court. VCCR, supra note 2, at art. 36(1)(b). It is preferable that consular notice be provided as early as possible so that the consulate may be of most assistance to its national. 
address this issue and improve compliance with the VCCR, legislation has been proposed in Illinois that would require judges to notify all defendants that if they are foreign nationals, they have a right to consular notification. ${ }^{225}$ If notice was not previously provided, the court is to take steps to remedy the situation.

Fourth and finally, the Second Circuit suggested that a "detained alien may be able to petition officials of a detaining authority, including where appropriate the courts, to comply with the obligations set forth in Article 36." ${ }^{226}$ This suggestion is the most puzzling, because it appears that is exactly what Mr. Mora did and the Second Circuit refused him any relief. As a more general matter, this suggestion would not work unless the detained alien discovers through some other source that he has a right to consular notification before he would be in a position to make such a petition. One of the purposes of consular notification is to inform the foreign national of his or her right to communicate with the consulate.

At a minimum, then, it is clear the United States owes its treaty partners some form of reparation for its breaches of the VCCR. Given that Article 36 is written in terms of an individual right to consular notice, a strong argument may be made that reparations are owed on an individual basis as well.

\section{CONCLUSION}

In Medellin, the U.S. Supreme Court described the United States' interest in "ensuring the reciprocal observance of the Vienna Convention, protecting relations with foreign governments, and demonstrating commitment to the role of international law . . . [as] plainly compelling,"227 Given the importance of this interest, it is imperative that federal, state, and local authorities find ways to ensure better compliance with the law of consular notification. Federal legislation spelling out methods for better implementation of the VCCR would be the most authoritative and instructive action. Absent such congressional action, however, courts can interpret the consular notification provisions of the VCCR as self-executing treaty provisions that provide an individual cause of action to foreign nationals who are arrested or detained in the United States. In addition, states can take it upon themselves to better implement consular notification, because it is usually state and local law enforcement officers who are responsible for the arrest and detention of foreign nationals. States may

225. Gen. Assemb. S.B. 1906, 97th Gen. Assemb. (Ill. 2011).

226. Mora v. New York, 524 F.3d 183, 198-99 (2d Cir. 2008).

227. Medellin, 552 U.S. at 524. 
accomplish better implementation through legislation, interpretative guidance, and educational programs, such as those underway in California, Texas, Oregon and Illinois. Doing so will ensure that the human rights of both U.S. citizens abroad and foreign nationals in the United States are respected. 